\title{
Climato-stratigraphic subdivision of the Pleistocene in Schleswig-Holstein, Germany and adjoining areas
}

\author{
status and problems
}

Hans-Jürgen Stephan

\section{Dedicated to Burchard Menke (1932-1993)}

How to cite:

Stephan, H-J. (2014): Climato-stratigraphic subdivision of the Pleistocene in Schleswig-Holstein, Germany and adjoining areas status and problems. - E\&G Quaternary Science Journal, 63 (1): 3-18. DOI: 10.3285/eg.63.1.01

Abstract:

In Schleswig-Holstein detailed petrographical and palynological studies were undertaken with samples from exposures and core drillings examined over the last four decades. Analyses of the gravel fraction and 'indicator rocks' of glacial deposits were used for stratigraphical interpretations and correlation. Glaciofluvial sediments were dated by TL and OSL. Combined with the stratigraphical information from organic deposits, a new climato-stratigraphic table of the Pleistocene for Schleswig-Holstein with a revised subdivision of the Middle and Late Pleistocene could be established. The pollen sequence of the oldest Pleistocene warm phase (Warmhörn-Thermomer) is published for the first time. The complete Early Pleistocene and lower Middle Pleistocene stratigraphical sequence is documented at Lieth and at Gorleben (Lower Saxony) in two continuous successions of organic beds developed during warm phases alternating with cold phase deposits. The uppermost part of the Lieth succession and the lowermost part of Gorleben overlap. The combined succession provides a unique reference for correlations through Europe.

No more than three cold stages involving glaciation are demonstrated to exist currently in Schleswig-Holstein, the Elsterian and the Saalian in the upper Middle Pleistocene, and the Weichselian in the Late Pleistocene. A possible pre-Elsterian glaciation is discussed. The Holsteinian is correlated with MIS 9e. The Saalian includes a lower part with non-glacial cold phases and warm phases, the 'Wacken-Warmzeit' (=Dömnitz) and the 'Leck-Warmzeit' correlated with MIS 7e and MIS 7c respectively, and a glacial upper part. During the Weichselian probably two phases of glaciation existed, the first in the early Middle Weichselian ('Ellund-Phase'; late MIS 4 or/and the early MIS 3), the second in the Upper Weichselian (MIS 2). The Weichselian glaciation of Schleswig-Holstein ends around $15 \mathrm{ka} \mathrm{BP}$ when huge stagnant and dead ice masses of the Young Baltic glacier advance ('Mecklenburg-Phase') melted.

Klimastratigraphische Gliederung des Pleistozäns in Schleswig-Holstein, Deutschland und angrenzenden Gebieten Stand und Probleme

Kurzfassung:

In Schleswig-Holstein wurden in den zurückliegenden vier Jahrzehnten detaillierte Untersuchungen an Probenmaterial aus Aufschlüssen und Kernbohrungen durchgeführt. Analysen der Kiesfraktion und von ,Leitgeschieben“ aus glazialen Ablagerungen wurden für die Interpretation und Korrelation genutzt. Glazifluviatile Sedimente wurden TL- und OSL-datiert. Zusammen mit der stratigraphischen Information aus organischen Ablagerungen konnte eine neue klimatostratigraphische Tabelle des Pleistozäns für Schleswig-Holstein mit revidierter Gliederung des Mittel- und Oberpleistozäns erstellt werden. Die Pollensequenz der ältesten pleistozänen Warmzeit (Warmhörn-Thermomer) wird erstmals veröffentlicht. Das Unterpleistozän (Altpleistozän) und das untere Mittelpleistozän sind bei Lieth und bei Gorleben (Niedersachsen) in zwei kontinuierlichen Schichtfolgen vollständig dokumentiert, abgelagert in einem Wechsel von warmen und kalten Klimaphasen. Der oberste Abschnitt der Abfolge von Lieth und der unterste der Abfolge von Gorleben überlappen. Die kombinierte Abfolge bietet ein einzigartiges Referenzprofil für Korrelationen innerhalb Europas.

Bisher wurden in Schleswig-Holstein nur drei Kaltzeiten mit Vergletscherungen nachgewiesen, Elster- und Saale-Kaltzeit im oberen Mittelpleistozän und die Weichsel-Kaltzeit im Oberpleistozän. Eine mögliche prä-elsterzeitliche Vergletscherung wird diskutiert. Die Holstein-Warmzeit wird mit MIS 9e korreliert. Das Saale umfasst einen unteren Abschnitt mit nicht-glaziären Kaltzeiten und mit Warmzeiten, der ,Wacken-Warmzeit' (=Dömnitz) und der ,Leck-Warmzeit', korreliert mit MIS 7e und MIS 7c, und einen glaziären oberen Abschnitt. Während des Weichsel gab es wahrscheinlich zwei Phasen mit Vergletscherung, die erste im frühen Mittelweichsel (,Ellund-Phase', spätes MIS 4 oder/und frühes MIS 3), die zweite im oberen Weichsel (MIS 2). Die weichselzeitliche Vergletscherung Schleswig-Holsteins endet um 15 ka BP, als großflächige stagnierende Eisflächen und Toteismassen des Jungbaltischen Gletschervorstoßes ('Mecklenburg-Phase') schmolzen.

Keywords: $\quad$ Pleistocene, climato-stratigraphic table, correlations, Schleswig-Holstein

H-J. Stephan, Köhlstr. 3, 24159 Kiel. E-Mail: hjuergenstephan@t-online.de

\section{Introduction}

The paper outlines the evidence for the Pleistocene of Schleswig-Holstein, Germany. It presents a stratigraphic scheme that is based on a correlation with the Quater- nary stratigraphy of the Netherlands and the Lower Rhine area and has been revised as a consequence of recent OSL and ${ }^{230} \mathrm{U} / \mathrm{Th}$ dates of deposits from Schleswig-Holstein and Lower Saxony. The oldest part of the Pleistocene sequence in Schleswig-Holstein is the 'Lieth-Serie' Beds (Menke 1970, 


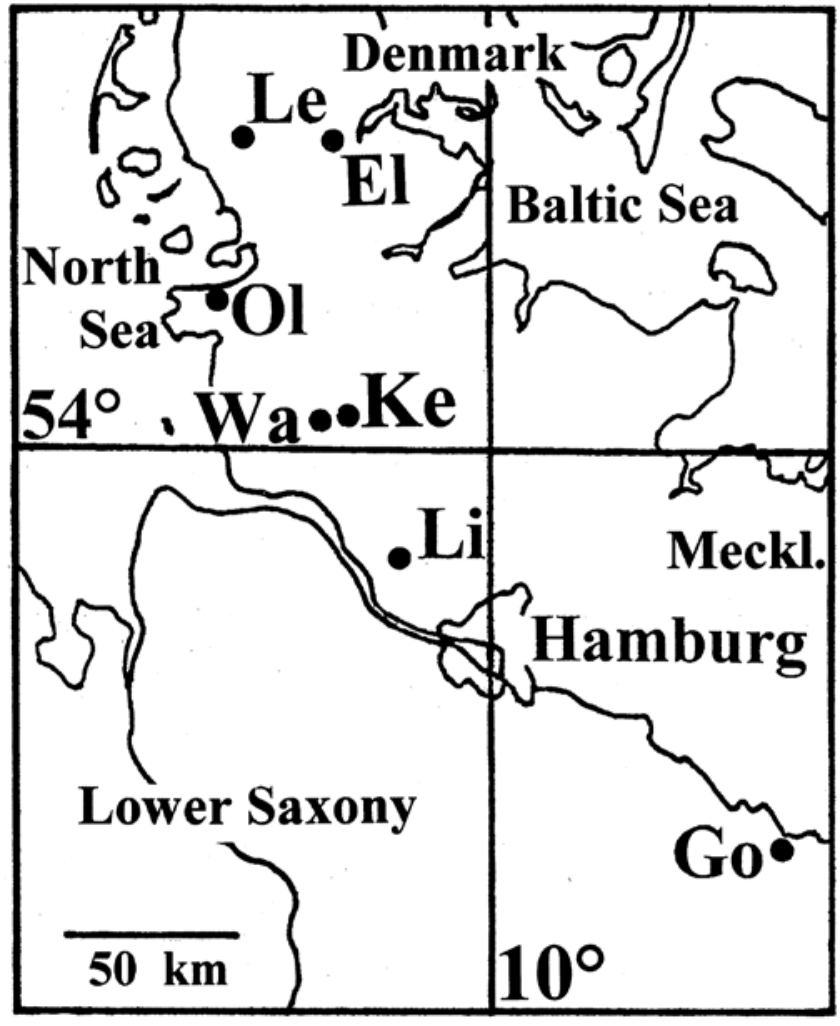

Fig. 1: Location map. El = Ellund, Go = Gorleben, $\mathrm{Ke}=$ Keller, Le $=$ Leck, $\mathrm{Li}=$ Lieth, $\mathrm{Ol}=$ Oldenswort, $\mathrm{Wa}=$ Wacken .

Abb. 1: Lagekarte.

1975) (Fig. 2, 3). In the neighbourhood (northeastern Lower Saxony), according to palynological investigations on cores from the top of the Gorleben salt dome (Fig. 1) by MüLLER (1986, 1992), the upper part of the 'Lieth-Serie' (Fig. 3: 'Dannesch-Komplex') is found again, however, there as the lowest part of the very long sequence of Gorleben. The 'DanneschKomplex' is followed by the pre-Elsterian middle part of the Gorleben succession, here named 'Gorleben-Complex'. Evidence is presented for Elsterian, Saalian and Weichselian glaciations (cf. BENDA 1995; EHLERs et al. 2004) which appear to be characterized by a cyclic pattern of ice-flow directions. It is suggested that ice advanced first from a northerly or northeasterly direction, to be succeeded by an ice stream from the east (e.g. WennBerg 1949; Woldstedt o DupHorn 1974; EISSMANN \& MÜLLER 1979). Northeast and eastward sourced ice reached North Germany in all glaciations, but there is evidence for ice from the north only during the Elsterian Glaciation. Each glaciation is represented by several ice advances (Fig. 3, blue bars at the right), which more or less differ in source area, flow direction, extent and composition of their deposits. German terms are given in quotation marks or - for better understanding - occasionally added in paraphrases behind the English terms. For cold phases (German: Kaltzeit) often the neutral term 'kryomer' is used (cf. LütTIG 1965, MenKe 1980, MüLlER 1992: kryomere), for warm phases the term 'thermomer' (German: Warmzeit). The term 'interglacial' is only used in citations, because none of the described thermomers seem to have separated glaciations.

All important sites mentioned in the text are given in Fig. 1.

\section{Early Pleistocene [Lower Pleistocene]}

The evidence for the 'Lieth-Serie' is recorded in a former limestone pit at Lieth in Holstein. The depositional site is a sinkhole on top of a salt dome and the sediments consist of a succession of lignite-like organic beds separated by sandy units. Palynological and stratigraphic investigations were carried out on the organic units by MENKE (1970, 1975) revealing gyttjas and a boreal Sphagnum-Ericales-peat. MENKE correlated the 'Lieth-Serie' with the Quaternary sequence of the Netherlands (ZAGWiJN 1960, 1963) and suggested that it is part of the Early Pleistocene (Fig. 2) and named it 'Ältestquartär' beginning at c. 2.6 Ma BP. [This age has only recently been formally fixed as the base of the Pleistocene by the IUGS (GIBBARD et al. 2010)]. Later MENKE (cf. STEPHAN \& MENKE 1993) additionally compared it with Early Quaternary deposits of the Lower Rhine (URBAN 1978) and palynological investigations published by ZAGWIJN \& DE Jong (1984). A full description of the stratigraphic members within this succession is given briefly by Behre in LitT et al. (2007).

The lowest part of the 'Lieth-Serie' consists of fluvial sands with some organic material in thin layers or streaks. In its upper portion organic material is more frequent and silty muds occur with pollen assemblages providing evidence for a warm phase, named the 'Warmhörn-Thermomer'. At Lieth these deposits are disturbed by salt-tectonic processes and are incomplete, but in a borehole from Oldenswort in western Schleswig-Holstein that succession was found well preserved, documented as a $40 \mathrm{~m}$ thick sequence (STEPHAN $\mho$ MEnke 1993). At this site, glacigenic Elsterian deposits cover the sediments of the 'Warmhörn-Thermomer', however, only their uppermost part has been eroded by the Elsterian glacier. The main elements of the pollen spectra are depicted in Fig. 4 and it can be seen that the typical Pliocene flora disappears at the base of the Quaternary. The break begins with the 'Kaltenhörn-Kaltzeit' which is the first cold phase (Kryomer) of the Lieth succession and the overlying organic beds reveal a stepwise decrease of 'exotic' pollen (Tertiary relics). STEPHAN \& MENKE (1993) used this vegetational evidence to derive a temperature curve (Fig. 2). The coldest phase of the Early Pleistocene seems to have been the 'Ekholt cold phase' ('Ekholt-Kaltzeit'). During this and other cold phases coarse sandy fluvial sediments were deposited over large areas of Northwest Germany, presumably in a subarctic environment. These deposits are exposed on the island of Sylt where they are known as the upper part of the 'Kaolinsand'. This unit contains sand blocks that could only have been transported in a frozen state and are considered to be indicators for very cold winters. Likewise very angular quartzite blocks within the 'Kaolinsand' indicate transport without edge abrasion and therefore are considered to have been transported by ice floes (Ehlers 1987, HAcht 1987). Similarities exist with a probably fluvial lag sediment exposed in the Rehburger end moraine in Lower Saxony containing up to boulder-sized Scandinavian erratics that are interpreted as belonging to the 'Complex of Hattem' (Ehlers, Meyer \& StePHAN 1984). Evidence of a glaciation in North Germany at that stage has not been found.

The first warm phase of the 'Gorleben Complex', the 'Osterholz-Warmzeit', still belongs to the Early Pleistocene (cf. LITT et al. 2007: supplement 1). 
Fig. 2: The Early Pleistocene ("Ältestquartär"), correlations and temperature curve. Original drawing by MENKE (STEPHAN \& MENKE 1993, Abb. 1). Petrographical column: Black = brown coal-like mud und peat; dotted $=$ sand ; vertical signature $=$ silty $/$ sandy brown coal (silt in cold phases). 1) MENKE 1975, 2) STREMME \& MENKE 1980, 3) ZAGWIJN \& DE fONG 1984, 4) ZAGWIJN 1960, 5) ZAGWIJN 1963, 6) URBAN 1978.

Abb. 2: Das Frühpleistozän („Ältestquartär"), Korrelationen und Temperaturkurve. Originalzeichnung von MENKE (STEPHAN \& MENKE 1993, Abb. 1). Petrographie-Säule: Schwarz = Braunkohleartige Gyttja und Torf; gepunktet $=$ Sand; senkrecht liniert = siltige/sandige Braunkohle (Silt in Kaltzeiten).
Sediments of the 'Gorleben-Complex' are not yet known from Schleswig-Holstein. They were preserved in a sinkhole formed by subrosion, quite similar to the conditions at Lieth. There, sediments of the 'Gorleben Complex' are underlain by deposits of the 'Dannesch Complex' (= Bavelium) comprising the upper part of the Lieth sequence, including the Uetersen warm phase, Elmshorn cold phase, Pinneberg warm phase and Dorst cold phase.

\section{Problems}

The age of the 'Lieth-Serie' could not be determined by physical methods. Magnetostratigraphic investigations failed, because magnetic grains in the sands between the organic beds are extremely rare. The correlation with the Early Pleis- tocene stratigraphy of the Netherlands as depicted in Fig. 2 and 3 seems questionable in some parts. In contrast to the Lieth succession, the Dutch organic layers represent shorter sequences with the organic beds showing hardly complete vegetational development, and have not yet been found in superposition.

In Fig. 3 the transition between the magnetostratigraphic Matuyama and Brunhes chronozones is used as the boundary between the Early Pleistocene and the Middle Pleistocene, as proposed by Head, Pillans \& Farquhar (2008). In this case at least the first warm phase ('Osterholz warm phase') and eventually also the second ('Hunteburg warm phase') of the 'Gorleben Complex' would be regarded as Early Pleistocene, as both show a reverse magnetization. LitT et al. 


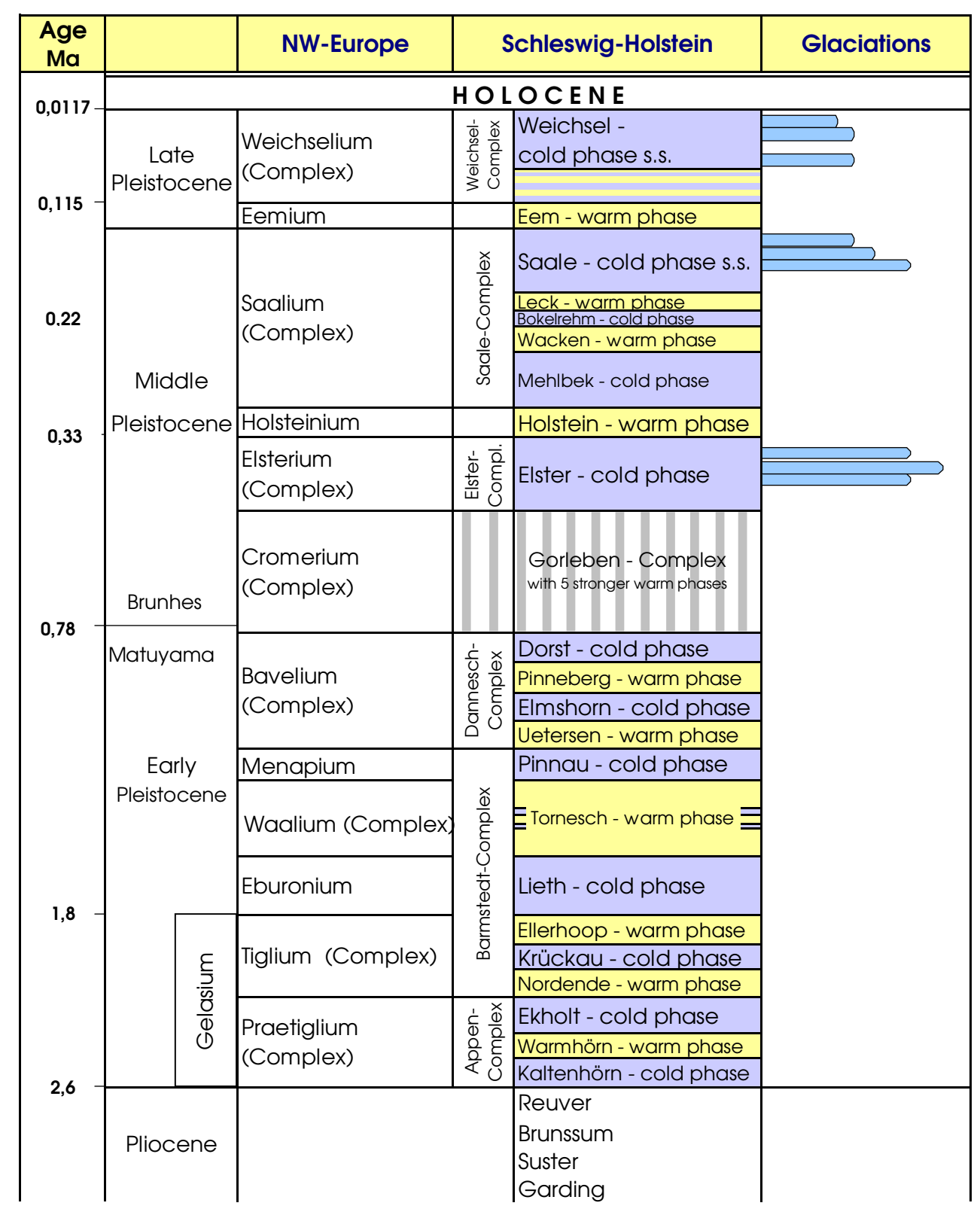

(Age axis not to scale)
Draft: H.-J. Stephan July 2003

Digital layout: M. Jagusch / C. Verdieck
Last update : July 2010

Digital layout: M. Jagusch / C. Verdieck
Last update : July 2010
Fig. 3: Climato-stratigraphical table of the Pleistocene in Schleswig-Holstein. Last updated September 2010 Layout influenced by the 'Stratigraphische Tabelle von Deutschland (STD)' (DSK 2000) and LITT et al. (2005). Vertical signature: Unit not found in Schleswig-Holstein so far. Abb. 3: Klimastratigraphische Tafel des Pleistozäns in Schleswig-Holstein. Zuletzt überarbeitet im September 2010. Gestaltung angelehnt an die ,Stratigraphische Tabelle von Deutschland (STD) ' (DSK 2000) und LITT et al. (2005). Senkrechte Signatur: In Schleswig-Holstein bisher nicht nachgewiesen.
(2007) include the second warm phase in the Middle Pleistocene and suggest correlation with the Lishi-Event with a reverse magnetization within the Brunhes chronozone, but discuss an alternative inclusion in the Early Pleistocene. From a vegetational point of view, the base of the cold phase succeeding the 'Osterholz warm phase' would represent a convincing boundary. After this cold phase the Tertiary relic Eucommia did not return (HAHNE et al. 1994).

\section{Middle Pleistocene}

The Middle Pleistocene is divided into an upper succession with glaciations and a lower non-glacial succession represented by the main part of the 'Gorleben Complex' (early Middle Pleistocene) in Fig. 3. The sediments of this complex were deposited during five major warm phases of interglacial rank and 7 shorter and weaker warm phases of interstadial character, interrupted by phases of cold but non-glacial climate (MÜLlER 1992). Two of the warm phases have not been given names until now. The upper Middle Pleistocene comprises the deposits of the Elsterian, the Holsteinian and the Saalian.

\section{Problems}

The correlation of the early Middle Pleistocene of the welldocumented 'Gorleben Complex' with the units of the socalled 'Cromer Complex' in Western Europe (ZAGwiJn, van MontFrans \& Zandstra 1971; Zagwijn 1996) is still in discussion (e.g. URBAN in STEPHAN et al. 2011). It seems to be not clear so far how to combine the 12 thermomers of the 'Gorleben Complex', especially the 5 warm phases of 'interglacial' rank with the warm events of the 'Gorleben Complex'. The number of known Cromerian warm stages in Western Europe is obviously incomplete yet. The same is true regarding the early Middle Pleistocene deposits of East Germany (e.g. EISSMANN 2004). 


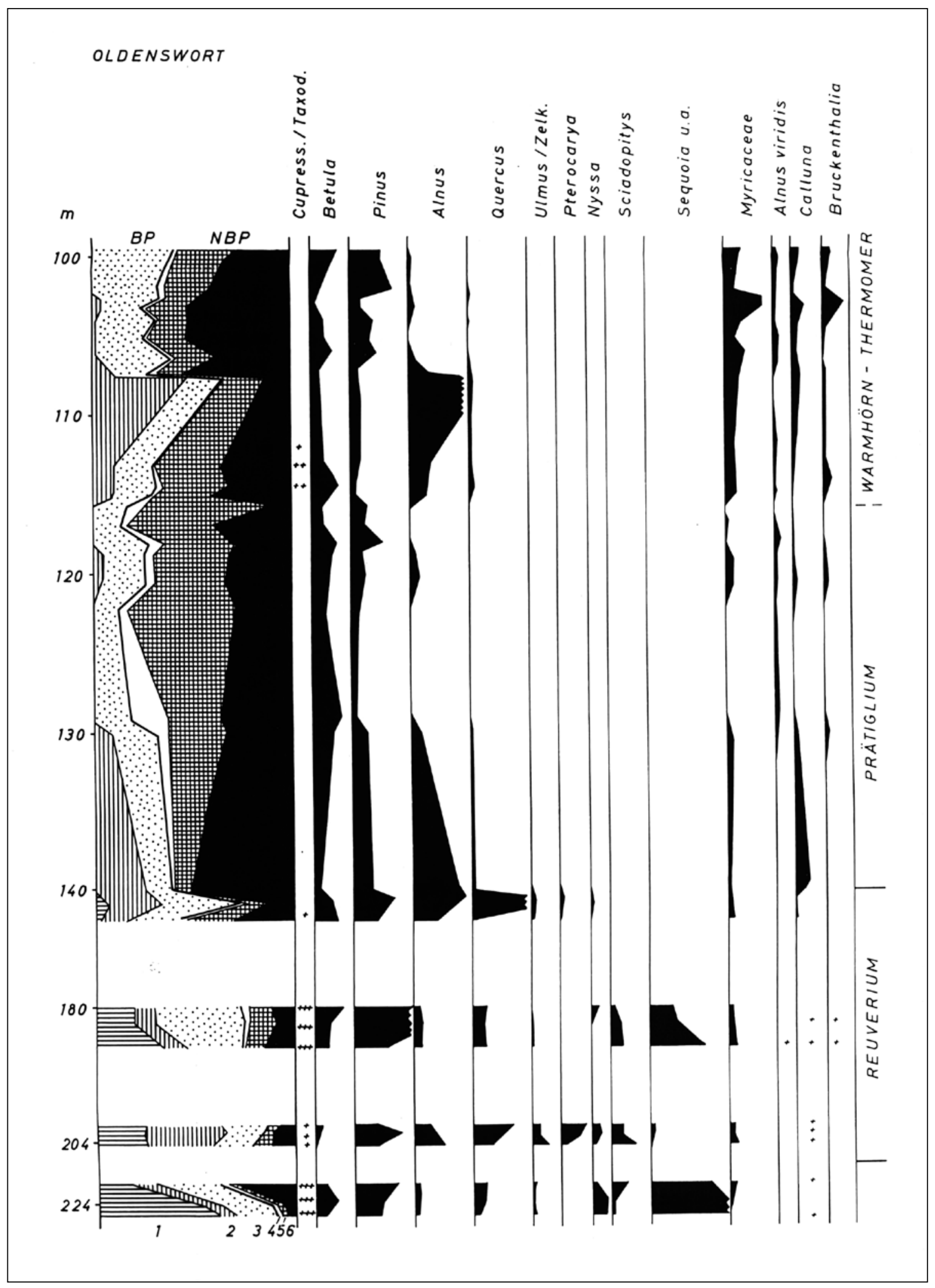

Fig. 4: Simplified pollen diagram (selected species) of the 'Warmhörn warm phase' ('Warmhörn-Warmzeit') (Lower Pleistocene) above Pliocene. Oldenswort drilling. Counts and original drawing by Menke (without year). $B P=$ pollen of trees and shrubs: $1=$ Sequoia and other typical Pliocene species, 2 = other thermophile species, $3=$ boreal species, including Myricaceae. $N B P=$ non-arboreal pollen: $4=$ herbs, $5=$ Poaceae, Cyperaceae, $6=$ Ericales.

Abb. 4: Vereinfachtes Pollendiagramm (ausgewählte Arten) der 'Warmhörn-Warmzeit' (Unter-Pleistozän) über Pliozän. Bohrung Oldenswort. Zählung und Originalzeichnung von Menke (ohne fahresangabe). BP = Pollen von Bäumen und Sträuchern: $1=$ Sequoia und andere typisch pliozäne Arten, 2 = andere wärmeliebende Arten, 3 = Boreale Arten, einschließlich Myricaceae. NBP = Nichtbaumpollen: $4=$ Kräuter, 5 = Poaceae, Cyperaceae, $6=$ Ericales. 


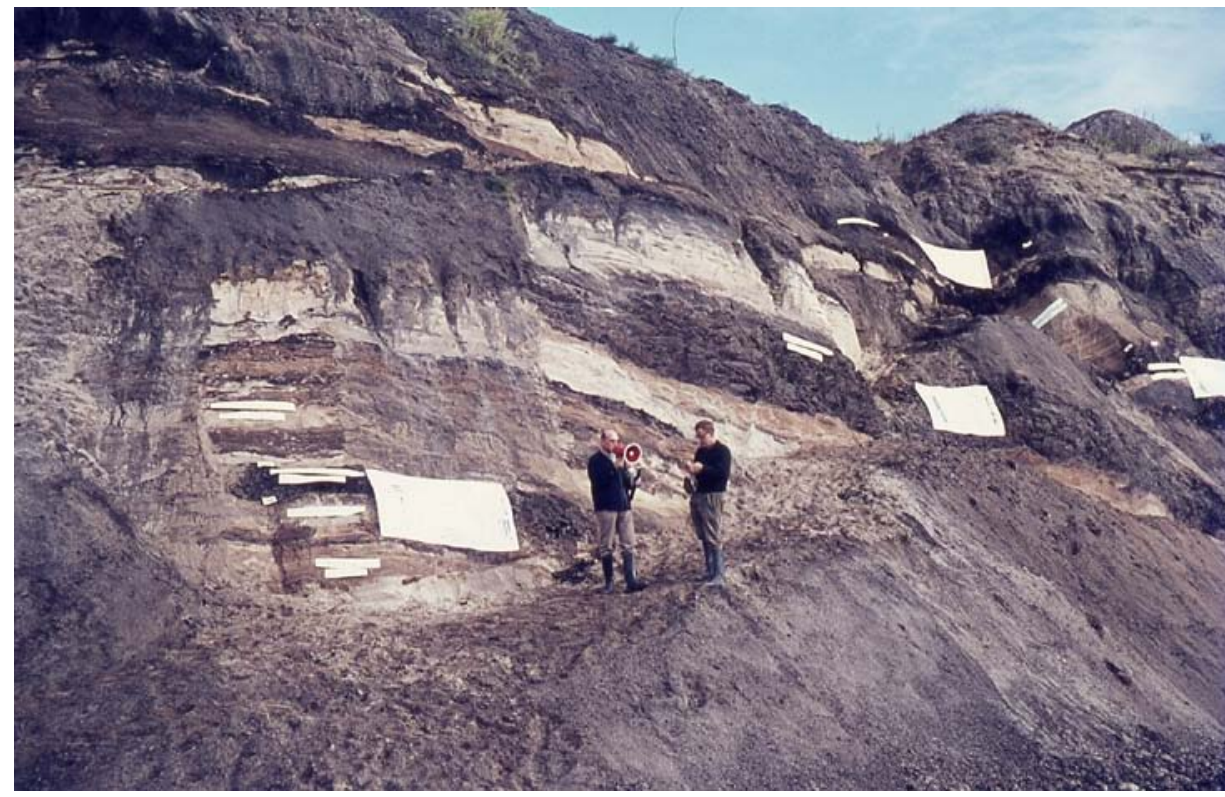

Fig. 5: The Lower Pleistocene Lieth succession in the Lieth open cast mine; dark bands = brown coal-like organic beds, white bands = sands (cf. EHLERS 1983, Fig. 243). In front: Helmut Stremme (with megaphone) and Burchard Menke. Photograph: H.-7. Stephan 1970.

$A b b$. 5: Die unterpleistozäne Lieth-Abfolge in der Grube Lieth; dunkle Lagen = braunkohlenartige organische Ablagerungen, weiße Lagen $=$ Sande $(v g l$. EHLERS 1983, Fig. 243). Vorne Helmut Stremme (mit Megaphon) und Burchard Menke. Foto: H.-f. Stephan 1970.

\section{Elsterian (Elster Complex; Elster-Kaltzeit)}

Deposits of the Elsterian are found close to the surface in a relatively narrow fringe in eastern Germany, in other regions in few elevated areas with only a thin cover of younger sediments and in some 'geological windows', or in disturbed positions where Elsterian beds were thrust upwards by younger glaciations. In most areas, however, Elsterian deposits were more or less eroded by younger glaciations. They are then most likely found in depressions and on the shoulders of deeply incised tunnel valleys, sometimes completely filling the valleys. Based on the well-investigated areas of Saxony, it was believed for a long time that there were two larger ice advances during the Elsterian (LITT et al. 2007). However, in Schleswig-Holstein evidence was found recently for three different till sheets, so that now a minimum of three glacier advances is proved (cf. KRONBORG 1986 for Denmark ). During the youngest of these, a 'Baltic ice stream' formed, with a source area in eastern Fennoscandia (STEPHAN 2007: Goldelund-Formation). The Elsterian 'red till' described from eastern Lower Saxony (e.g. Meyer 1976) probably belongs to this advance. Between the youngest glacier advance and the preceding glaciations a short period of subarctic climate with a regional decay of the ice sheets seems probable (STEPHAN et al. 2011).

At the end of the Elster cold phase, glaciolacustrine 'Lauenburg Clay' or equivalent mostly fine-grained deposits are found widespread in North Germany, especially on top of the infill of tunnel valleys. Within this late glacial deposit an early and short ingression of the sea is documented by an arctic macrofauna in deep tunnel valleys of southwestern Holstein (Hinsch 1993) and in western Mecklenburg by arctic species of foraminifera (MüLLER \& OBST 2008). After this event, probably due to fast isostatic uplift, the marine influence ceased. A second transgression occurred shortly before the onset of the Holsteinian warm stage, but still under arctic or subarctic conditions.

Due to its complex development the Elsterian is now often referred to as 'Elster Complex' (Fig. 3). The Elsterian is correlated with MIS 10 (LITT et al. 2007). Its age is indirectly determined by dating deposits of the youngest thermomer of the 'Gorleben Complex' ('Rhume-' or 'Bilshausen-Warmzeit'; MÜLLER 1992) and of the Holsteinian (see below).

\section{$\underline{\text { Problems }}$}

No older sediments of glacial origin than Elsterian have been reliably found in North Germany so far. VINX, GRUBE \& GRUBE (1997), however, discuss an older till, found at the base of the glacial sequence at Lieth. They regard this local till as a 'pre-Elster-1 Till', because they interpret the overlying clayey till as Elsterian-1. However, it has to be kept in mind that Elsterian tills are extremely variable in composition, resulting from mostly strong reworking and incorporation of material from the local to regional subsurface. In North Germany it is mainly reworked Tertiary material that makes up the clayey, silty, and sandy till matrix. So, for instance, the existence of an extremely sandy till of the second glacier advance in northwestern Lower Saxony (MEYER 1976, 1987) does not exclude a clayey till of the same glaciation phase deposited at Lieth. Both the first and the second till and also the so-called 'pre-Elster-1 till' contain pebbles and blocks from western Scandinavian source areas with a distinctive component of rocks from the Oslo region.

It can, however, not be ruled out that North Germany was reached by a pre-Elsterian glaciation. In Central Jutland (Denmark) ANDERsEn (1965) found 'pre-Harreskovian' glacial deposits including a clayey till. As the 'HarreskovThermomer' - according to Urban (in STEPHAN et al. 2011) correlates with the second thermomer of the 'Gorleben Complex' (Hunteburg warm phase) at least north of the Danish/ German borderline an early Middle Pleistocene glaciation is proved.

Hitherto no evidence for such old glaciation was found in Schleswig-Holstein. However, erosion by Elsterian glaciers and meltwater was obviously very strong. It seems possible that deposits of an older glaciation were more or less completely eroded during that period, perhaps with the exception of some local remnants in protected depressions. It is, for instance, not clear how the sediments below the organic 
bed of Surheide that has been correlated with the Ferdinandovian by BeHre (2004) must be interpreted. According to Urban (in STEPHAN et al. 2011) the vegetational history of the really warm 'Surheide-Thermomer' was found to be similar to the 'Hunteburg-Thermomer'. If this correlation is correct and if the underlying sediments are glacial, as believed, one must deduce a pre-Elsterian glaciation extending at least into northwestern Lower Saxony. It might have reached North Germany as early as the end of the Early Pleistocene or the onset of the Middle Pleistocene, i.e. much earlier than ever thought previously. Behre alternatively discusses the inclusion of the Ferdinandovian into the 'Elster Complex' which would result in a much broader definition of the term Elsterian.

The solution of this problem depends on a detailed investigation of the petrographical composition and origin of the sediments below the organic bed of Surheide.

Hitherto it is not known whether the two Elsterian tills of East Germany (WANSA in LITT et al. 2007) can be correlated with the tills found in Northwest Germany. It is also unknown, how far the individual ice advances reached. The late Elsterian 'Baltic ice' must have covered at least northwestern and southern Lower Saxony where LüTTIG (e.g. 1999) and Meyer (LütTIG \& MEYER 2002) found Elsterian tills with the majority of erratics from more easterly source areas ('ElsterE-tills') than deduced for other Elsterian tills.

\section{Holsteinian (Holstein warm phase; Holstein-Warmzeit)}

The 'classical' Holsteinian is well documented in North Germany, and several detailed investigations of marine deposits and non-marine organic beds have been published. Its name was introduced by GeIKIE (1894: 441). He called the marine deposits in southwestern Schleswig-Holstein 'Holstein bed'. Its lower and upper boundaries are clearly defined by INQUA and the Subcommission on European Quaternary Stratigraphy (SEQS) (JERZ \& LINKE 1987). Type region is the Lower Elbe area. According to ${ }^{230} \mathrm{U} / \mathrm{Th}$-dating (GEYH \& MüLLER 2005), it is synchronous with Marine Isotope Stage 9 (MIS 9), which is supported by ages of Infrared-Radiofluorescence (IR-RF)-dated early Saalian sands (Krbetschek, Degering \& Alexowsky 2008; Krbetschek \& Stephan 2010) with ages between $141 \mathrm{ka} \mathrm{BP}$ and c. $300 \mathrm{ka}$. IR-RF-dated 'flaser sands' of the Wacken succession in western Holstein lying between Holsteinian marine beds and sands of the Mehlbek cold phase yielded an age of $296 \pm 21$ ka (KRBETSCHEK $\mho$ STEPHAN 2010).

A brief definition and description of the Holsteinian is given by Litt (in LiTT et al. 2007).

\section{Problems}

The age of the Holsteinian is increasingly debated. Several scientists (e.g. Koutsodendris et al. 2010; SARnthein, Stremme \& MANGini 1986, publishing U/Th- and ESR-ages of shells), especially from western Europe, believe this strong thermomer belongs to MIS 11 (cf. TURNER 1996, EHLERS 2010). The question arises whether both, the 'Holsteinian' from western Europe and the Holsteinian from North Germany, in fact describe different warm phases.

At Schöningen (brown coal mine) in Lower Saxony organic deposits overlying late Elsterian sediments were palynologically investigated by URBAN (e.g. 1995, 2007; URBAN et al. 2011). Beside clear Holsteinian sequences Urban described profiles with different palynological successions, one of them displaying a distinct 'interglacial' character. She named it the 'Reinsdorf Interglacial' and interpreted it as a thermomer younger than the Holstein warm phase. Contrary to her several scientists correlate this organic bed with the Holsteinian (e.g. MEYER 2012), an interpretation that seems to be no longer completely rejected by URBAN (URBAN \& SiERrALTA 2012). However, during an excursion of the Subkommission Quartär der deutschen Stratigraphische Kommission (DSK) in 2011 to the Schöningen mine Urban presented a carefully prepared section with the Holsteinian bed at the base and the Reinsdorf horizon several metres above.

The age of this warm phase is strongly debated. ${ }^{230} \mathrm{U} / \mathrm{Th}$ data (e.g. SiERRALTA et al. 2012) seem to fix this thermomer approximately in the range of MIS 9 thus intensifying the debate about the age of the 'classic Holsteinian'. Regarding the weakness of the climatic optima of MIS 9a or 9c in the $\delta D$ record of ice cores (e.g. JouzEL et al. 2007), a connection of the Reinsdorf as a clearly warm thermomer with them seems to be unlikely.

Hitherto deposits of the Reinsdorf thermomer and succeeding interstadials are unknown in Schleswig-Holstein.

\section{Saalian (Saale Complex)}

The Saalian can be roughly divided into a non-glacial lower and a glacial upper part, the 'Saale cold phase s.s.' (STEPHAN 2005: 'Glaziäre Saale-Subgruppe'). However, at closer inspection the Saalian comprises a complex succession of cold and warm phases as depicted in Fig. 3. The 'Wacken warm phase' and the 'Leck warm phase' are recently recognized as members of the Saalian. In the Wacken clay pit a continuous stratigraphical sequence was exposed, reaching from late Elsterian glaciolacustrine Lauenburg Clay via marine Holsteinian clay, fine grained sands with ripple marks ('flaser sands'), several metres thick deposits of the Mehlbek kryomer (so-called 'white sands' coarsening upwards and including a thick kerkoboloid-layer in its upper part), to peat and gyttja of the Wacken warm phase (Fig. 6, 7) (MENkE 1968; DüCKER 1969). The organic bed is overlain by fine-grained white sands very similar to the underlying periglacial sands, probably deposited in a succeeding cold phase, named 'Bokelrehm cold phase' in Fig. 3. (This new name was derived from the village of Bokelrehm located c. $2 \mathrm{~km} \mathrm{NW}$ of the Wacken clay pit). Upwards they rapidly become coarser and are discordantly cut by meltwater(?) sands.

According to IR-RF dating by KRBETSCHEK, the Wacken warm phase seems to correlate with MIS 7e (KRBETSCHEK \& STEPHAN 2010).

The Leck succession was described by STEPHAN (2006b), results of different studies were published by STEPHAN et al. (2011). In the drillings north of Leck (North Frisia) a c. $9 \mathrm{~m}$ thick fluvial sand was found containing streaks or layers with organic sand or silt and a thicker bed with a sandysilty mud of the 'Leck-Warmzeit' s.s.. The vegetational development of the Leck warm phase is different from that of the Eemian, Holsteinian, the Wacken and also the Reinsdorf succession as described by URBAN (e.g. 1995, 2007); URBAN, Sierralta \& FrEchen (2011). It is believed to correlate with MIS 7c (STEPHAN et al. 2011). An organic bed in the clay pit Nachtigall near Höxter, Northrhine-Westfalia, with very similar pollen assemblages (cf. also KLEINMANN et al. 2011) 

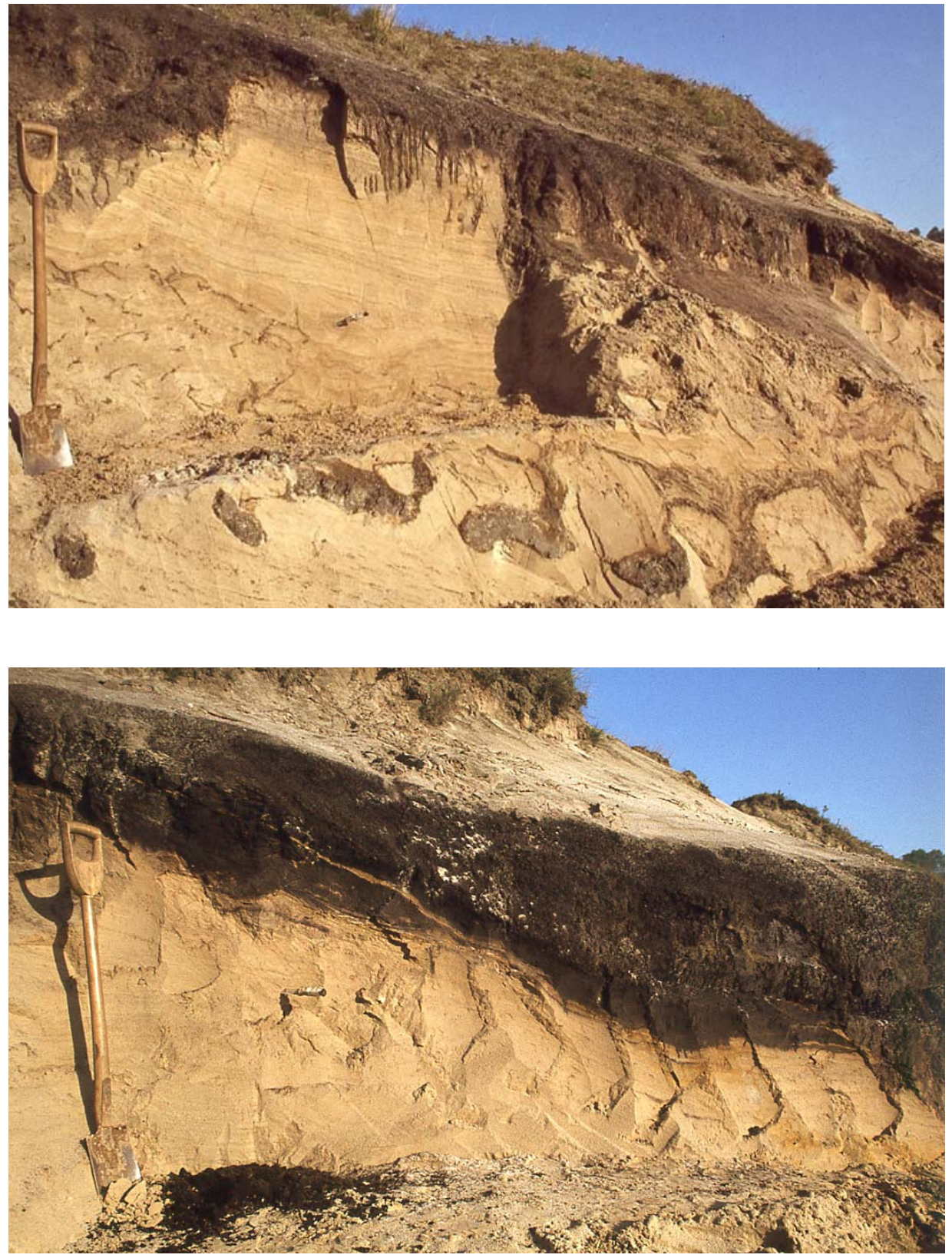

Fig. 6: Wacken clay pit. Periglacial deposits of the 'Mehlbek cold phase' ('Mehlbek-Kaltzeit') displaying a horizon with strong involutions (kerkoboloids), at the right overlain by the organic bed of the 'Wacken warm phase' ('Wacken-Warmzeit'). Photograph: H.-7. Stephan 1978.

Abb. 6: Tongrube Wacken. Periglaziale Ablagerungen der,Mehlbek-Kaltzeit ${ }^{*}$ mit einem Horizont mit starker Verbrodelung (Kerkoboloide). Rechts Überlagerung durch die organischen Ablagerungen der Wacken-Warmzeit. Photo: H.-F. Stephan 1978.
Fig. 7: Wacken clay pit. The organic bed of the 'Wacken warm phase' (peat beneath gyttja) below sands of the 'Bokelrehm cold phase' (new term) overlying sands of the 'Mehlbek cold phase'. Photograph: H.-7. Stephan 1978.

Abb. 7: Tongrube Wacken. Die organischen Ablagerungen der Wacken-Warmzeit (Torf unter Gyttja) unter Sanden der Bokelrehm-Kaltzeit (neuer Begriff) und Sande der Mehlbek-Kaltzeit überlagernd. Foto: H.-J. Stephan 1978. show ${ }^{230} \mathrm{U} / \mathrm{Th}$ ages ranging from $227+9 /-8$ ka to $201+15 /-13$ ka (KLEINMANN, LePPER \& WAAS 2011).

The two Saalian glaciation phases found in Saxony can probably both be correlated with the first Saalian glacial phase of North Germany, the Drenthe Stadium (LitT et al. 2007). Between the Drenthe Stadium and the succeeding Warthe Stadium an ice-free phase occurred in North Germany, either due to a weak amelioration of climate, or to a decrease of snowfalls in the southern Scandinavian highlands. It is not known where the active ice margin was located during the 'interphase'. At least in the westernmost areas of NW Germany, for instance in Dithmarsia, the ice sheet melted down and the landscape became partly ice-free. The land surface was altered by periglacial processes, and features typical for an arctic environment formed. The climate obviously never reached interstadial conditions. Neither soils nor organic beds have been found anywhere (cf. STEPHAN 1980; Meyer 1987, 2005; MüLler 2004). The bleached loam in the Saalian Drenthe till of the 'Rotes Kliff' (red cliff) sec- tion on the island of Sylt was originally interpreted as an 'interglacial' and later as an interstadial soil (FELIX-HeNNINGSEN \& URBAN 1982; FELIX-HENNINGSEN 1983), covered by a Warthian till. STEPHAN \& MENKE (1993) questioned this interpretation. Most likely the older Saalian (Drenthian) till was bleached during the Eemian and the Early Weichselian interstadials and then, during the cold phases of MIS 4 and MIS 3 (see chapter Weichselian), covered by a fresher sheet of periglacially reworked (not bleached) till material from nearby. Both, the Drenthian till and its periglacial cover then underwent further weathering during the Middle and Late Weichselian interstadials and the Holocene.

In Schleswig-Holstein, south of Kiel, meltwater deposits overlain by a Saalian basal till yielded OSL ages between 164 $\pm 27 \mathrm{ka}$ and $199 \pm 19 \mathrm{ka}$ (Preusser 1999) and TL ages between c. $127 \pm 19 \mathrm{ka}$ and $131.4 \pm 19.7 \mathrm{ka} \mathrm{BP}$ (MARks et al. 1995). According to recent IF-RF-dating by KRBETSCHEK, DEGERING \& Alexowsky (2008), sandy sediments of the glacial upper part of the Saalian in Central and East Germany are no older than 
$150 \mathrm{ka} \mathrm{BP}$ and no younger than $130 \mathrm{ka} \mathrm{BP}$, thus having been deposited within a period of only $20 \mathrm{ka}$.

\section{Problems}

The subdivision of the glacial Saalian is not at all clear. According to WoldSTEDT $(1926,1954)$ glaciers reached North Germany during two different large stadials, the 'DrentheStadium' and the 'Warthe-Stadium'. However, in Northwest Germany three different widespread Saalian till sheets exist and even more till facies are to be found. For many decades glacial geologists tried to find out methods for associating Saalian deposits with either the first or the second stadium. Petrographical analyses of tills, especially gravel analyses and counts of Scandinavian 'indicator rocks' ('Leitgeschiebe') were used. Deposits of the Drenthe Stadium were supposed to be characterized by a 'Swedish-dominated' drift, deposits of the Warthe Stadium by a stronger 'Baltic' influence (rocks from East Fennoscandia and the base of the eastern Baltic Sea), due to (climate-induced?) fundamental changes in the main source areas and stream directions of the ice sheet. Consequently, all Saalian deposits not characterized by a 'Baltic' composition, were associated with the Drenthe Stadium (LütTIG 1957, 1991, 1999; LÜTTIG \& MEYER 2002; MeYer 1976, 2005). However, StePHAN (1980, 1998) pointed out that both stadia showed a cyclic development with an earlier drift characterized by mainly Swedish rocks and a later drift characterized by relatively frequent Balticor East Baltic components. A 'Baltic to East Baltic facies' is revealed by the so-called 'red Drenthe till' in Northwest Germany overlying a succession with a Swedish-dominated composition and also by the typical Warthian drift (in SEHolstein and NE-Lower Saxony often again with a 'red till'; EHLERS 1992) overlying Swedish-dominated deposits. Using this model STEPHAN (1980) attributes all tills younger than the 'red Drenthe till' to the Warthian, including the so-called 'Kreidemoräne', rich in flint and often also in chalk, which corresponds to the description of WoLDSTEDT (1954) but not of Woldstedt (1926). MEyer (2005) disregards those results and refers to that till as 'Drenthe-2 Till' or the 'younger Drenthe Till', in agreement with LüTTIG (e.g. 1991, 1999).

To avoid confusion and in agreement with the stratigraphical rules in Schleswig-Holstein (STEPHAN 1995) and partly in Hamburg (GRUBE 1981) regional terms are applied. In publications focussing on larger national or international correlation, often the neutral terms Saalian 'older', 'middle' and 'younger advance' (or till) have been used (e.g. KABEL 1982, StePHAN 1982, 1987, 1998, EhLERs 1990) (see LithoLex at www.bgr.bund.de/litholex).

The 'Kreidemoräne' is often regarded as the typical facies of the middle Saalian ice advance in NW-Germany deposited by a 'Northeast Ice' that had derived abundant Cretaceous material from the southern Danish islands. It is normally used as the stratigraphically defining horizon. However, lately this facies has also been found in older Saalian (for instance in Dithmarsia) and - in northern SchleswigHolstein and in neighbouring Denmark - in younger Saalian deposits. There till rich or extremely rich in chalk was deposited by an 'East Ice'. Furthermore, it became evident that middle Saalian tills in southwestern Schleswig-Holstein and northwestern Lower Saxony accumulated much chalk and flint from glacial erosion on the tops of salt domes in south- western and central Holstein. At least, a 'Kreidemoräne' of Weichselian age has lately been detected at the outermost Weichselian margin in southern Holstein (hills of 'Kisdorfer Wohld') (STEPHAN 2011). Much fresh chalk and unweathered flint without abrasion (observed in the fine gravel fraction) prove the till as a 'local till' that had incorporated Cretaceous material from the top of a salt dome nearby. These hills, interpreted as a Saalian endmoraine previously, now can be understood as a Weichselian push moraine. Similarities exist with chalk-rich deposits of the oldest Weichselian glacier advance in Mecklenburg during the Warnow stadial (RüHBERG et al. 1995, MüLlER 2004).

Thus incorporation of abundant chalk and flint in tills is not restricted to one stratigraphical horizon in large parts of Northwest Germany and can no longer be used there for stratigraphical correlations. The only exception might be East Holstein situated east of the belt of high-lying salt domes.

In Mecklenburg only two widespread Saalian till horizons are known, and none of them is a 'Kreidemoräne' (MüLLER 2004). In Brandenburg tills rich in chalk and flint have been associated with the 'younger stadium of the Saalian' by LippStreu, Brose \& MARCineK (1995). However, until now no overlying Eemian deposits have been found, and this till facies might eventually be determined to be of Weichselian age.

It is still controversially discussed how far the youngest Saalian ice sheet reached in Schleswig-Holstein. Due to finds of 'East Ice' material in fine gravel samples from northwestern Schleswig-Holstein, STEPHAN (1998) drew the ice margin through the island of Sylt towards the northwest, following RICHTER (1937). This line seems to correspond with the extent of the 'Warthian' in Jutland (HoUMARK-NiELSEN 2007). However, this concept is rejected by LÜTTIG (2009). Relying on counts of indicator rocks in northernmost Schleswig-Holstein, he interprets all deposits in the northwest as older Saalian (Drenthian facies or his lately defined North Frisian facies).

Also in southern Schleswig-Holstein the outermost limit of the younger Saalian ice advance is still unknown.

During the early decay of the Saalian ice shield, temporary re-advances in Schleswig-Holstein terminated increasingly in the east. Their deposits are progressively 'Balticdominated' probably due to increased ice supply via the recent Baltic Sea Basin. Extremely Baltic to East Baltic ice advanced through this depression presumably caused by a faster melting of West Swedish ice that had blocked westward drainage of the eastern ice masses previously (cf. the Weichselian 'Young Baltic Advance'; StePHAN 2001). Baltic and finally East Baltic ice reached Mecklenburg, northeastern Lower Saxony, and Schleswig-Holstein. Baltic ice even reached Jutland, time-transgressive from southeast towards northwest and north. The northernmost 'red tills' of East Baltic origin are found southwest of Kiel. Further to the north reddish tills of Baltic origin occur, characterized by abundant reddish-violet sandstones and quartzites derived from the sedimentary rocks covering the crystalline basement of East Fennoscandia (Jotnian and Eocambrian sandstones). Both facies overlap in Central Holstein.

However, it must be emphasized that the younger Saalian ice also deposited tills with a facies similar to Drenthian tills besides Baltic and East Baltic facies (c.f. KABEL 1982). One reason is the fact that the ice sheet eroded and incorporated 


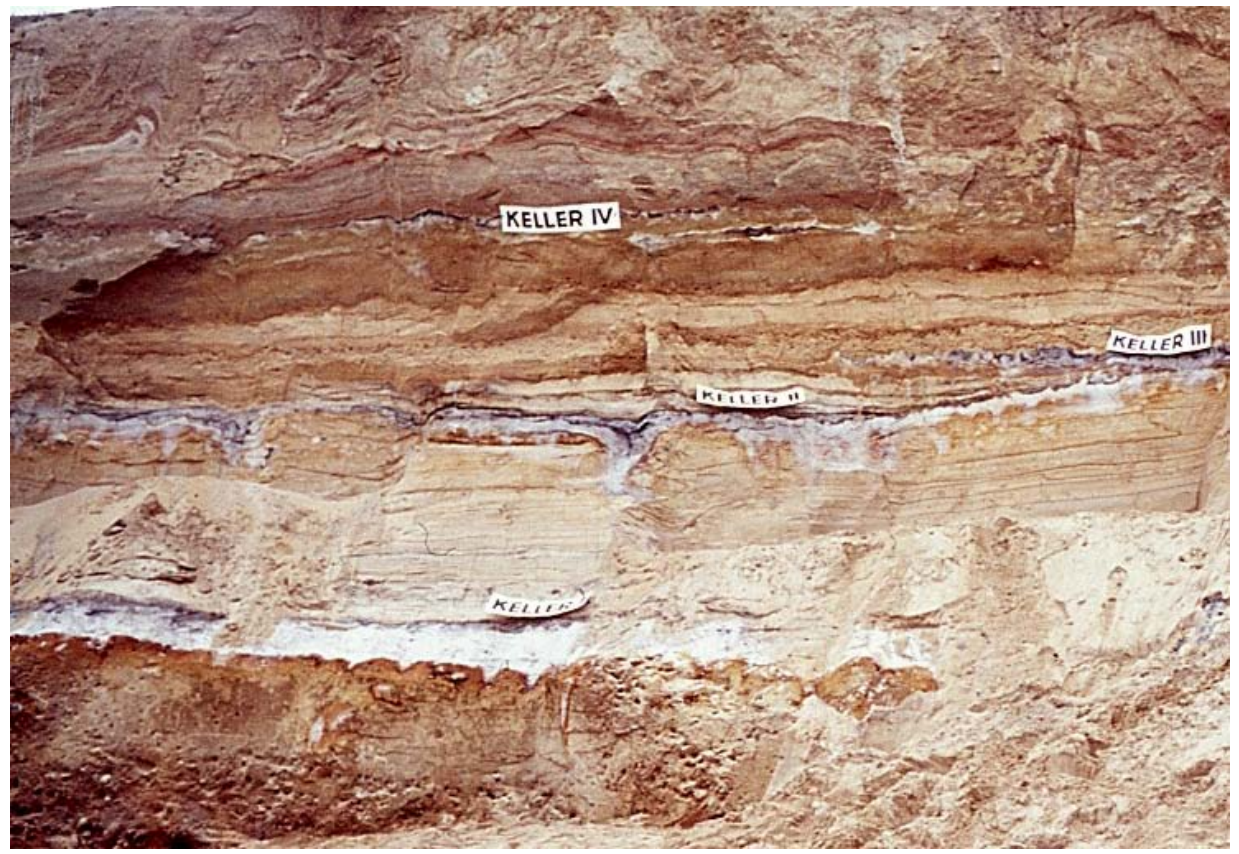

Fig. 8: Eemian and Early Weichselian soils in the sand pit of Hof Keller, type section of the Keller Interstadial. From bottom to top: Distinct Eemian podsol (Keller I), Brörup podsol (Keller II), relic of the Odderade podsol (Keller III), and a thin and weak podsol of the Keller Interstadial (Keller IV), in the right half bipartited. Photograph: H.-7. Stephan 1976.

Abb. 8: Eem- und früh-weichselzeitliche Böden in der Sandgrube Hof Keller, Typprofil des Keller-Interstadials. Von unten nach oben: Ausgeprägter Podsol des Eem (Keller I), Podsol des Brörup (Keller II), Erosionsrest des Odderade-Podsols (Keller III) und ein dünner, schwach entwickelter Podsol des Keller-Interstadials (Keller IV), in der rechten Hälfte zweigeteilt. Foto: H.-7. Stephan 1976.

much older glacial material resulting in 'mixed facies'. They are difficult to interpret by counts of erratics or by gravel analyses. The degree of mixing probably increased the further to the west or south the ice sheet advanced.

Furthermore, a primary mixing could already have occurred when 'tributary ice streams' flowing down the Swedish mainland towards southeast (cf. drawing by STEPHAN in EHLERS, MEYer \& STEPHAN 1984: Fig.11) added their drift to the 'Baltic ice stream' flowing through the Baltic Basin. As a result the northwestern ice band of the Baltic ice stream transported material with a composition similar to older Saalian tills. South of Sweden it turned towards west and even northwest (now as the northern band). Till deposited by this stream band would erroneously not be interpreted as deposit of the younger Saalian ice ('Warthe-Till') by counting indicator rocks.

\section{Late Pleistocene [Upper Pleistocene]}

\section{Eemian (Eem warm phase, Eem-Warmzeit)}

Eemian deposits were found and investigated in numerous sites in Schleswig-Holstein (e.g. MENKE 1976) and other parts of North Germany and Europe. The Eemian vegetational and climatic development seems well known. The correlation with MIS 5e is nowhere called in question. For a short description see LiTT et al. (2007).

In North Germany the marine transgression flooded all river valleys along the coasts of the Baltic Sea and the North Sea (cf. Höfle, MERKT \& Müller 1985). Remarkably, Eemian deposits lie deeper than one would expect considering that a warm thermomer with higher than recent temperatures should be accompanied by a higher sea level. South of Lübeck a typical Eemian beach sediment was found in a drilling at c. $-28 \mathrm{~m}$ below the recent sea level (NN). This means a subsidence of that region by c. $0.25 \mathrm{~mm}$ p.a. on average since $120 \mathrm{ka}$, which agrees with the epirogenetic sinking of the Lower Elbe region in geological time.

In land areas not affected by the transgression, Eemian peats or gyttjas developed in many depressions, later covered either by periglacial sediments or - in the 'young morainic landscape' - by glacial Weichselian deposits. Eemian soils are frequently found (cf. Figs. 8, 9), providing a good base for the stratigraphical separation of Middle and Late Pleistocene deposits.

\section{Weichselian (Weichsel Complex, Weichsel-Kaltzeit)}

The Weichselian is subdivided into the Lower (or Early) Weichselian, usually correlated with MIS $5 \mathrm{~d}$ to $5 \mathrm{a}$, the Middle Weichselian, correlated to MIS 4 and 3, and the Upper (or Late) Weichselian (MIS 2). The lower part is characterized by cold phases (stadials) alternating with interstadials. In contrast to conventional stratigraphic tables (DSK 2002, LiTT et al. 2007), the Eemian in Fig. 3 is followed at least by three Lower Weichselian interstadial horizons (cf. Fig. 8 , 9,10 ). Short descriptions of the first 2 interstadials (Brörup, Odderade) were given by BEHRE (in LitT et al. 2007). For more detailed descriptions see e.g. Menke (1975) and AverDIECK (1967). The third interstadial (Keller) was described by MENKE (1980). In exposures in Schleswig-Holstein frost cracks, thin convoluted layers, and horizons with ventifacts prove that the Lower Weichselian cold phases saw at least temporary subarctic to arctic conditions. In an exposure in the northernmost Schleswig-Holstein (Osterbylund) in the stadial sediment separating the interstadial Brörup- and Odderade-soils, a mass flow deposit ('Fließerde') with stones and even blocks derived from a thrust Saalian till body has recently been observed (cf. Fig 9), proving a temporary moist arctic climate.

The lower Weichselian interstadials precede a very cold arctic phase between c. 72 and 60 ka BP (JouzEL et al. 2007, Wolff et al. 2010). Its base is thought to mark the beginning of the Middle Weichselian (MIS 4) (see below). In 1994 in northern Schleswig-Holstein first hints were found for a glaciation probably taking place during this phase. TL dating of meltwater deposits yielded ages between $59.4 \pm 8.9 \mathrm{ka}$ and $52.5 \pm 7.9$ ka (MARKs et al. 1995). Later Preusser (1999) pub- 


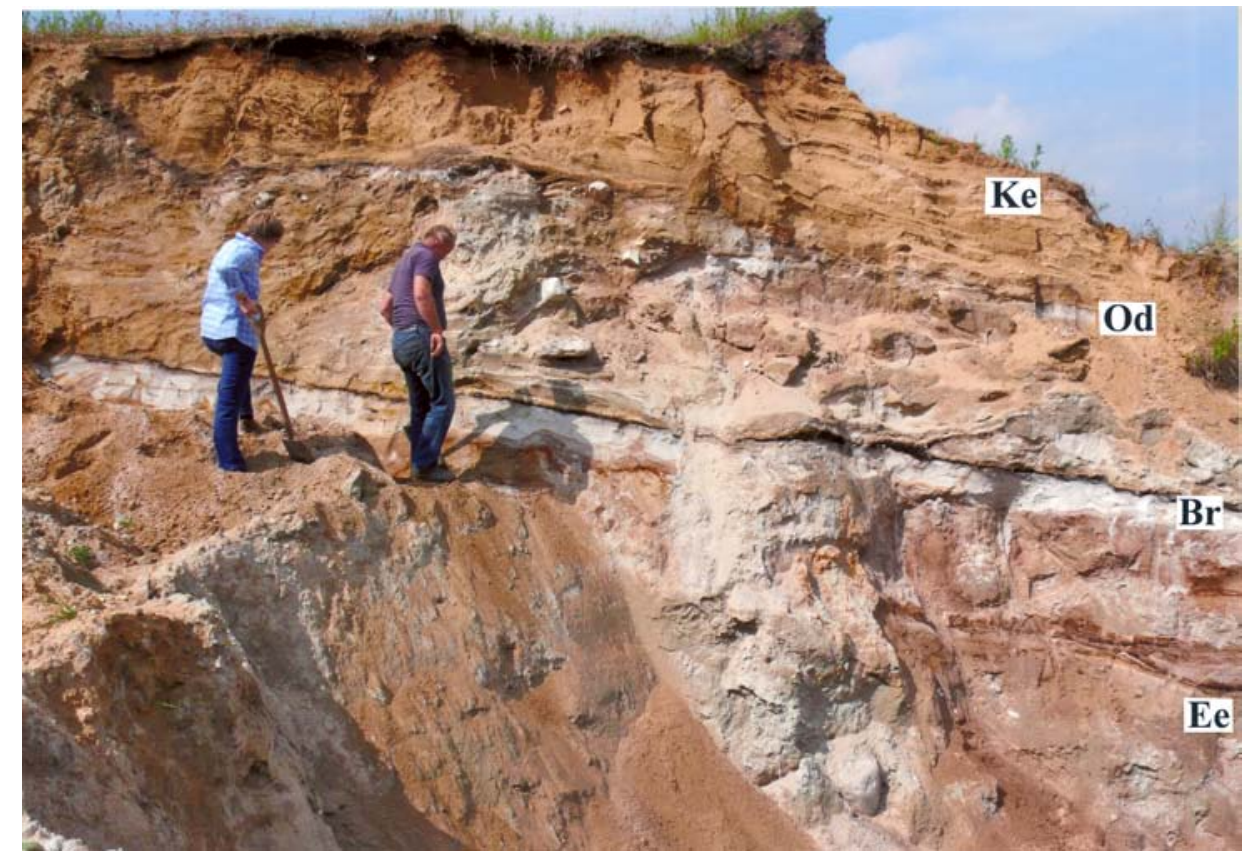

Fig. 9: Osterbylund sand pit WNW of Ellund (Fig.1). At the base (right) Saalian till transformed to an Eemian gley (Ee), overlain by Early Weichselian sediments with a thick podsol of the Brörup Interstadial (Br), a podsol of the Odderade (Od), and a very weak podsol of the Keller Interstadial (Ke) at the top. Between the Brörup podsol and the Odderade podsol a mass flow deposit of the Rederstall Stadial is visible in the centre and further left. Photograph: H.- F. Stephan 2012.

Abb. 9: Sandgrube Osterbylund WNW von Ellund (s. Abb. 1). Rechts unten saalezeitlicher Till, zu einem eemzeitlichen Gley (Ee) verwittert, überlagert von früh-weichselzeitlichen Sedimenten mit einem mächtigen Podsol des Brörup $(\mathrm{Br})$ einem Podsol des Odderade (Od) und einem sehr schwachen Podsol des KellerInterstadials (Ke) (z. T. verwaschen).

Zwischen Brörup- und Odderade-Podsol kann man in der Bildmitte und links davon eine Fließerde erkennen. Foto: H.-f. Stephan 2012

lished OSL-dates between $92 \pm 24 \mathrm{ka}$ and $61 \pm 16 \mathrm{ka}$. The consistency of ages pointing to the lower Weichselian or early Middle Weichselian is the main reason for the assumption of such an early glaciation. The cold phase was named 'EllundPhase' by STEPHAN (2003) (cf. STEPHAN 2006a: Ellund-Formation). It is in rough agreement with the postulated age of the so-called 'Old Baltic ice advance' in Denmark (PETERSEN $\approx$ KRONBORG 1991) or the synonymous 'Ristinge Glaciation' (HoumARK-NiELSEN 2007). This glaciation was probably induced by the arctic 'Ellund-Phase'. HoumArK-NiELSEN (2010) using OSL dates of meltwater deposits believes that glaciation to have taken place not earlier than $54 \mathrm{ka}$ ago in the north-western Baltic region, that means during the early phase of the succeeding weak warming.

Recently a Lower Weichselian glaciation has also been deduced by MüLler (2004: 'Warnow-Stadial', 2007: 'Warnow-Formation'), based on core samples from northwest Mecklenburg. There, marine deposits or an organic horizon ('Saßnitz-Interstadial') overlay the glacial deposits. According to Müller $(2004,2007)$ it was the strongest of all Weichselian glaciations terminating in most cases south of the LGMline drawn by EHLERs et al. (2004). Its till (qw0-till) is often rich in flint and chalk (RüHBERG et al. 1995) and is thought to have been commonly mistaken as the 'Saale III till' in older publications (e.g. CEPEK et al. 1975).

After the 'Ellund-Phase' the Middle Weichselian continued as a mainly cold period with several slightly milder interruptions. It lasted c. $30 \mathrm{ka}$.

The upper Weichselian comprises the pleniglacial with glacier advances during the 'Brandenburg-Phase', 'Frankfurt-Phase', 'Pommern-Phase' and 'Mecklenburg-Phase' (LitT et al. 2007; cf. LithoLex data bank) and the phase of late Weichselian interstadials. It ends at $11.7 \mathrm{ka} \mathrm{BP}$, based on correlation with the NGRIP ice core (RASMUSSEN et al. 2006; WALker et al. 2009). During the 'Mecklenburg-Phase', which is synonymous with the 'Young Baltic advance' in Schleswig-Holstein and Denmark (STEPHAN 2001), again a
'Baltic ice stream' originated, called the 'Young Baltic ice advance' (STEPHAN 2001), similar to the end phases of Elsterian and Saalian glaciations (cf. last paragraph of chapter Saalian). Ice masses, especially from an ice dome in the northeast of Scandinavia and from tributary ice streams from Central Sweden, flowed along the recent Baltic Sea Basin turning west and then northwest towards the Kattegat and Skagerak, very likely due to the melting of former blocking ice in the west. This was probably augmented by a simultaneous isostatic uplift of the southern areas of Pomerania and North Germany in response to deglaciation. 'Baltic ice' covered the northern Mecklenburg and the east of Schleswig-Holstein. In tills of this phase layers or streaks of 'red till' occur, characterized by many clasts of reddish or violet sandstones or quartzites (most are Jotnian sandstones) and Palaeozoic limestones. 'Baltic crystalline' (e.g. Åland rocks or Baltic porphyries) is rather rare in deposits of the Young Baltic ice advance in Schleswig-Holstein. Probably a northwestern to northern band of the Baltic ice stream reached its coastal regions (cf. EHLERS, STEPHAN \& MEYER 1984: Fig. 11) predominantly depositing a 'Svecobaltic facies' (STEPHAN 2003) that was mainly derived from eastern Sweden, the adjacent subground of the recent Baltic Sea and the islands of Oland and Gotland.

In the western Baltic area, the Young Baltic ice advance probably ended at about $15 \mathrm{ka} \mathrm{BP}$, when kame sediments TLand OSL-dated by Preusser (1999) were deposited between stagnant and melting ice masses, approximately contemporaneous with the end of the last pleniglacial cold phase that was followed by rapid warming (STUIVER, GROOTES \& BRAZIUNAS 1995).

\section{$\underline{\text { Problems }}$}

Dating of the Weichselian deposits in Schleswig-Holstein is still uncertain. It is, for instance, debatable whether TL dates and OSL dates for the assumed early Middle Weichselian glaciation are reliable or not. It cannot be ruled out that 


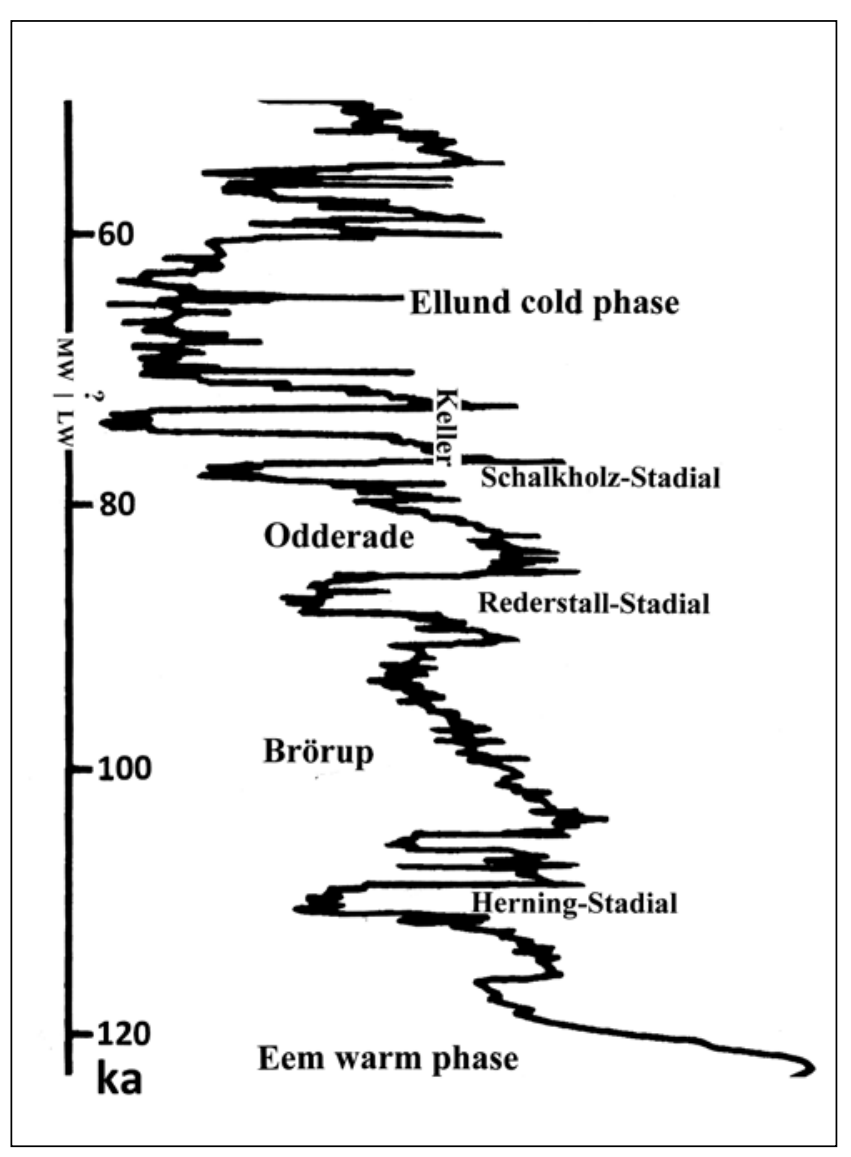

Fig. 10: Stratigraphical table of the Lower Weichselian of Schleswig-Holstein correlated with the $\delta^{18} \mathrm{O}$ record (simplified curve) of NGRIP ice core. MW / LW: Transition Lower Weichselian - Middle Weichselian? The period Odderade - Keller corresponds with stage MIS $5 a$ (cf. BoND et al. 1993).

Abb. 10: Stratigraphische Tabelle des Unterweichsel von Schleswig-Holstein, korreliert mit der vereinfachten $\delta^{18} \mathrm{O}-$ Kurve des NGRIP Eiskerns. MW $/ L W$ : Übergang Unterweichsel - Mittelweichsel? Der Abschnitt Odderade - Keller entspricht dem marinen Isotopen-Stadium $5 a$ (MIS 5a) (vgl. Bond et al. 1993).

measured grains were not completely bleached by sunlight before deposition, resulting in an overestimation of their age.

The position of the 'Keller-Interstadial' could be debated. Menke (1980) proposed to include the Keller into the Lower Weichselian. He assumed that it correlates with the 'OerelInterstadial' of Lower Saxony that was found above a Lower Weichselian sequence including peats of the Brörup and Odderade. The Oerel peat was ${ }^{14} \mathrm{C}$-dated (BeHre \& VAN DER Plicht 1992) revealing an age between 53.5 and $57.7 \mathrm{ka}$. Behre (in LiTT et al. 2007) associated the Oerel to the Middle Weichselian. This discrepancy could have several reasons:

1. Correlation of the Keller interstadial and the Oerel interstadial is wrong. However, the continuous sequences with Lower Weichselian interstadial soils (or sometimes organic layers) above clear organic Eemian in Schleswig-Holstein and the continuous sequence with organic horizons above organic Eemian at Oerel in Lower Saxony (BEHRE \& LADE 1986) plead for synchronism of these successions.

2. The inclusion of the Keller interstadial in the Lower Weichselian could be wrong. However, in the four known depressions in Schleswig-Holstein where the complete succession Eemian - Brörup - Odderade - Keller separated by stadials was found (cf. Fig. 8, 9) continuous deposition of periglacial niveofluviatile to eolian sediments was observed in the stadial beds. Intensive cryoturbations as indications for a strong change of climatic conditions which must be expected during a glacial event as the succeeding cold Ellund phase and glaciation occur first above the Keller horizon. Therefore, the association of the Keller interstadial to the Lower Weichselian seems to be plausible.

3. The inclusion of the Oerel interstadial in the Middle Weichselian could be wrong. This connection was supported by the ${ }^{14} \mathrm{C}$-dating of the peat of the Oerel bed. The question arises whether conventional radiocarbon dates of more than 50 ka published by BeHRe \& VAN DER Plicht (1992) are reliable or not. Important arguments for the assumption that the radiocarbon dates yield too young ages are the climatic records observed in the ice cores of Greenland and Antarctica (Stuiver \& Grootes 2000, Grootes et al. 2001, JouzEl et al. 2007, WolfF et al. 2010). In the NGRIP ice core of Greenland the uppermost part of the Odderade thermomer has an age around $80 \mathrm{ka} \mathrm{BP}$ (cf. Fig. 10), quite different to the ${ }^{14} \mathrm{C}$-age of c. $60.8 \mathrm{ka} \mathrm{BP}$ of the analogous part of the Odderade peat from the Oerel drilling (BEHRE \& VAN DER PliCHT 1992).

In Schleswig-Holstein, in three depressions with the Lower Weichselian sequence one soil of the 'Keller-Interstadial' was observed hitherto above the Odderade soil, succeeding the 'Schalkholz-Stadial' (cf. Fig. 10). In $\delta^{18} \mathrm{O}$ records of Weichselian successions the attributive thermomer is marked as Dansgaard-Oeschger Event 20 and part of the Lower Weichselian (cf. WolfF et al. 2010). Special problems arise, however, because Menke at the type locality of Hof Keller used the name 'Keller-Interstadial' for a short complex of two separated thin and weak soil horizons. It is the only site where two post-Odderade soils have been found. Probably they document weathering during the weak thermomers of the Dansgaard-Oeschger Events 19 and 20. Unfortunately WolfF et al. (2010) and others place the transition Lower/ Middle Weichselian between these events. As a consequence the older soil would be part of the Lower Weichselian (MIS 5), the younger soil part of the Middle Weichselian (MIS 4). Dansgaard-Oeschger Events 19 and 20 are interrupted by a short but very cold phase (perhaps caused or at least strongly influenced by the Lake Toba 'Mega-eruption'?). On the one hand this sharp interruption could be well used for the establishment of a boundary. On the other hand, however, in marine environments climatic records are less detailed. There the strong drop of temperature and the transition to a long-lasting cold period (Ellund cold phase) are commonly found at c. $70 \mathrm{ka} \mathrm{BP}$ (e.g. Jouzel et al. 2007). The same is true for the $\delta^{18} \mathrm{O}$ record of Taylor Dome in Antarctica (GROOTES et al. 2001). The onset of the Ellund cold phase after the Dansgaard-Oeschger Event 19 therefore seems to fit better with the beginning of the Middle Weichselian and MIS 4 (cf. Bond et al. 1993).

It cannot be ruled out that the two thin and weak soil horizons of Keller in fact correlate with both the Oerel and the Glinde interstadial of Lower Saxony. The thin organic bed of the 'Glinde-Interstadial' would then represent the last weak thermomer of the Lower Weichselian.

The age of the first upper Weichselian glacier advances cannot be finally determined in North Germany. It might be younger than $24 \mathrm{ka}$ BP (cf. STEPHAN in LITT et al. 2007). That suggests a delay between the strong cooling around 26 
ka BP (Stuiver or Grootes 2000), the climatic onset of the Upper Weichselian (or even around $30 \mathrm{ka} \mathrm{BP,} \mathrm{cf.} \mathrm{WolfF} \mathrm{et}$ al. 2010), and the advance of the ice sheet. LüthGENS et al. (2010), however, according to new OSL dates of fluvioglacial sediments in north-eastern Germany suggest a first ice advance already during early MIS 2.

The Brandenburg and the Frankfurt Advances were originally morphostratigraphically defined by WoLDSTEDT (1926, 1928). It is unclear whether they are independent advances or whether the latter was just a readvance of the former without deposition of an individual till sheet. The complicated petrographical and stratigraphical situation was briefly discussed by Stephan, Müller \& von Bülow (2008). Lüthgens, BöSE $\&$ KRBETSCHEK (2009) found evidence for a complex origin of the so-called Frankfurt end moraine. They question its origin as the terminal ridge of the 'Frankfurt(Oder) Phase'. A similar debate concerns the glacier advances during the 'Pommern-Phase' and the 'Mecklenburg- Phase'. Some scientists are of the opinion that both advances belong to the same glaciation phase (e.g. SchUlz 2003; LÜTTIG 2005). Theoretically all glacier advances of the Weichselian Pleniglacial might be combined into only two larger glacial events separated by a phase of gradual melting ('interphase').

The extent of the Weichselian ice advances in W-Mecklenburg and Schleswig-Holstein is not yet clear. The morphological connection of end moraines from Pomerania and Brandenburg to the west is partly debatable. In northern East Holstein the end moraine-lines are interrupted by a landscape dominated by Saalian uplands and strong Weichselian erosion. Stratigraphical correlations using counts of indicator rocks (TGZ-method) by LÜTTIG (e.g. 2004, 2005) provide no solution. Lüttig concludes that the Brandenburg Advance did not reach western Mecklenburg and Schleswig-Holstein and that the Pomeranian Advance ended in East Holstein, and that no evidence for the Mecklenburg Advance exists. So in eastern Central Holstein, in the Schleswig district, and further to the north, all Weichselian deposits should belong to the 'Frankfurt(Oder) Phase'. However, at least the distribution of two 'Young Baltic' tills in Denmark (HOUMARKNIELSEN 2007) and their continuation southwards (STEPHAN 2001) contradict this view.

The dating of Weichselian end moraines or deposits results in different ages, depending on the methods used. The youngest controversy arose regarding the age of the Pomeranian end moraine. ${ }^{10} \mathrm{Be}$ exposure dates of erratic blocks by RiNTERKNECHT et al. (e.g. 2006) yielded an average age of $14.6 \pm 0.3 \mathrm{ka} \mathrm{BP}$. This seems to be much too young (cf. Müller, StePHAN \& vON BülOw 2009). The postulated age lies in the time of the Late Weichselian strong warming (Stuiver, Grootes $\mho$ Braziunas 1995; Rasmussen et al. 2006). The main reason might be that the investigated blocks did not reach their final position at the time of the formation of the end moraine due to long-lasting melt of stagnant and buried ice and continuing periglacial movements (MÜLLER, STEPHAN \& VON BÜLOW 2009; STEPHAN \& MÜllER 2007; cf. Houmark-Nielsen et al. 2012). LÜthgens, BöSE \& KrbetSCHEK (2009) found an OSL age about 20 ka BP for Pomeranian outwash sediments in north-eastern Brandenburg, an age that seems to be much more convincing.

The first Late Weichselian climatic amelioration is often correlated with the Bölling Interstadial. However, UsINGER
(1995) made it clear that the Bölling is synonymous to the lower part of the Alleröd and not identical with the first Late Weichselian interstadial that occurred earlier (Hippophae maximum). The latter was defined by MENKE in Bock et al. (1985) and named 'Meiendorf-Interstadial'. Calibrated ${ }^{14} \mathrm{C}$ dates suggest an age of more than $14 \mathrm{ka} \mathrm{BP}$. This corresponds to the first intensive Late Weichselian warming between 14.7 ka and 14.2 ka BP (Stuiver, Grootes \& Braziunas 1995; RASMUSSEN et al. 2006).

\section{Conclusions}

By evaluating all information about the stratigraphic position of Pleistocene deposits in Schleswig-Holstein and adjoining areas including detailed petrographical studies of the sediments, palynological investigations, and dating by physical methods it has been possible to establish a reliable stratigraphical table, based on the regional climatic development. This table is valid not only for Schleswig-Holstein but for North Germany in general and can provide an update for the Pleistocene in the stratigraphical table for Germany (STD), (LiTT et al. 2005, 2007: Beilage 1). It can be used as an actual base for chronostratigraphical correlations of Pleistocene successions throughout Europe.

\section{Acknowledgements}

This work is an extended and updated version of a poster presentation at the 'Exploratory workshop on the frequency and timing of glaciations in northern Europe (including Britain) during the Middle and Late Pleistocene' in Berlin, February 2009. For the invitation I have to thank Margot Böse, FU Berlin.

I would like to thank the members of the laboratory for geotechnics of the Geological Survey of Schleswig-Holstein (former LANU S.-H.), especially Wanda Bienert, Barbara Kaczirek and Siegfried Neumann, for petrographical analyses and preparation of samples for gravel and stone counts, Marion Jagusch and Christina Verdieck (LLUR S.-H.) for their help during the construction of the stratigraphical table. I am grateful to reviewers of E\&G and Jürgen Ehlers, Peter Kershaw, and Jim Rose for helpful professional comments and improving the English of the manuscript.

\section{References}

ANDERSEN, S.T. (1965): Interglacialer og Interstadialer i Danmark. - Meddelelser fra Dansk Geologisk Forening, 15(4): 486-506.

Averdieck, F.-R. (1967): Die Vegetationsentwicklung des Eem-Interglazials und der Frühwürm-Interstadiale von Odderade / Schleswig-Holstein. Fundamenta, B2 (Frühe Menschheit und Umwelt, Teil II): 101-125, Taf. 24-28; Köln/Graz (Böhlau Verlag).

BeHre, K.-E. (2004): Das mittelpleistozäne Interglazial von Surheide. - Eiszeitalter und Gegenwart, 54: 36-47.

BeHre, K.-E. \& LADE, U. (1986): Eine Folge von 4 Weichsel-Interstadialen in Oerel/Niedersachsen und ihr Vegetationsablauf. - Eiszeitalter und Gegenwart, 36: 11-36.

Behre, K.-E. \& VAN DER Plicht, J. (1992): Towards an absolute chronology for the last glacial period in Europe: radiocarbon dates from Oerel, northern Germany. - Vegetation, History and Archaeobotany, 1: 111-117; Berlin.

Benda L. (1995): Das Quartär Deutschlands. - 408 S.; Berlin (Gebr. Borntraeger).

Bock, W., Menke, B., Strehl, E. \& Ziemus, H. (1985): Neuere Funde des Weichselspätglazials in Schleswig-Holstein. - Eiszeitalter und Gegenwart, 35: 161-180, 2 Taf.. 
Bond, G., Broecker, W., Johnsen, S., Mcmanus, J., Labeyrie, L., Jouzel, J. \& BonANI, G. (1993): Correlations between climate records from North Atlantic sediments and Greenland ice. - Science, 365: 143-147.

Cepek, A., Hellwig, D., Lippstreu, L., Lohde, H., Ziermann, H. \& ZwirNER, R. (1975): Zum Stand der Gliederung des Saale-Komplexes im mittleren Teil der DDR. - Zeitschrift geologischer Wissenschaften Berlin, 3(8): 1049-1075.

DSK (Hrsg.) (2002): Stratigraphische Tabelle von Deutschland (STD) 2002.

Dücker, A. (1969): Der Ablauf der Holstein-Warmzeit in Westholstein. Eiszeitalter und Gegenwart, 20: 46-57.

Ehlers, J. (1983): Glacial Deposits in North-West Europe. - 470 pp., Rotterdam (A.A.Balkema).

EHLERS, J. (1987): Die Entstehung des Kaolinsandes von Sylt. - In: НACHT, U. von (Hrsg.): Fossilien von Sylt II: 249-267; Hamburg.

EHLERS, J. (1990): Reconstructing the dynamics of the North-West European ice sheets. - Quaternary Science Reviews, 9: 71-83.

EHLERS, J. (1992): Origin and distribution of red tills in North Germany. Sveriges Geologiska Undersökning, Ca 81: 97-105.

EhLERs, J. (2010): Das Eiszeitalter. - 363 S.; Heidelberg (Spektrum Akademischer Verlag)

Ehlers, J., Meyer, K.-D. \& Stephan, H.-J. (1984): The pre-Weichselian glaciations of North-West Europe. - Quaternary Science Reviews, 3: 1-40; Oxford etc. (Pergamon).

Ehlers, J., Eissmann, L., Lippstreu, L., Stephan, H.-J. \& WANSA, S. (2004) Pleistocene Glaciations of North Germany. - In: EHLERs, J. \& GibBARD, P.L. (eds.): Quaternary Glaciations - Extent and Chronology, Part I Europe: Developments in Quaternary Science, Vol. 2a: 135-145; Amsterdam (Elsevier)

EISSMANN, L. (2004): Reduced to the Maximum: Mitteleuropäisches Quartär im Spiegel hochverdichteter geologischer Schnitte. - Mauritiana, 19(1) 1-16; Altenburg.

EIsSMANN, L. \& MüLlER, A. (1979): Leitlinien der Quartärentwicklung im norddeutschen Tiefland. - Zeitschrift geologischer Wissenschaften Berlin, 7(4): 451-462.

Felix-Henningsen, P. (1983): Paleosols and their stratigraphical interpretation. - In: EhLERs, J. (ed.): Glacial Deposits in North-West Europe: 289295; Rotterdam (Balkema).

Felix-Henningsen, P. $\mho$ Urban, B. (1982): Paleoclimatic interpretation of a thick Intra-Saalian paleosol, the "Bleached Loam" on the Drenthe Moraines of Northern Germany. - Catena, 9: 1-8.

GEIKIE, J. (1895): Classification of European glacial deposits. - The Journal of Geology, III(3): 241-269; Chicago.

GEYH, M.A. \& MüLLER, H. (2005): Numerical 230U/Th dating and a palynological review of the Holsteinian/Hoxnian interglacial. - Quaternary Science Reviews, 24: 1861-1872.

Gibbard, P.L., Head, M.J., Walker, M.J.C., and the Subcommission on QUATERNARY STRATIGRAPHY (2010): Formal ratification of the Quaternary System/Period and the Pleistocene Series/Epoch with a base at 2.58 Ma. - Journal of Quaternary Sciences, vol. 25: 96-102.

Grootes, P.M., Steig, E.J., Waddington, E.D., Morse, D.L. \& NAdEAU, M.J. (2001): The Taylor Dome Antarctica ${ }^{18} \mathrm{O}$ record and globally synchronous changes in climate. - Quaternary Research, 56(3): 289-298.

Grube, F. (1981): The subdivision of the Saalian in the Hamburg Region. Mededelingen Rijks Geologische Dienst, 34(4): 15-25.

НАснт, U. voN (1987): Spuren früher Kaltzeiten im Kaolinsand von Braderup / Sylt. - In: HAcht, U. von (Hrsg.): Fossilien von Sylt II: 269278; Hamburg.

Hahne, J., Mengeling, H., Merkt, J. \& Gramann, F. (1994): Die HunteburgWarmzeit („Cromer-Komplex“) und Ablagerungen der Elster-, Saaleund Weichsel-Kaltzeit in der Forschungsbohrung Hunteburg GE 58 bei Osnabrück. - Geologisches Jahrbuch, A 134: 117-166.

Head, M.J., Pillans, B. \& Farquhar, S. (2008): The Early - Middle Pleistocene Transition: characterization and proposed guide for the defining boundary. - Episodes, Journal of International Geoscience, 31(2): 255-259.

Hinsch, W. (1993): Marine Molluskenfaunen in Typusprofilen des ElsterSaale-Interglazials und des Elster-Spätglazials. - Geologisches Jahrbuch, A138: 9-34.

Höfle, H.-C., Merkt, J. \& Müller, H. (1985): Die Ausbreitung des EemMeeres in Norddeutschland. - Eiszeitalter und Gegenwart, 35: 49-59.

HoumArk-Nielsen, M. (2007): Extent and age of Middle and Late Pleistocene glaciations and periglacial episodes in southern Jylland, Denmark. - DGF, Bulletin of the Geological Society of Denmark, 50: 9-35.

Houmark-Nielsen, M. (2010): Extent, age and dynamics of Marine Isotope Stage 3 glaciations in the southwestern Baltic Basin. - Boreas, 39: $343-359$.
Houmark-Nielsen, M., Ling, H., Fabel, D., Schnabel, C., Xu, S., Wilcken, K.M. \& BINNIE, S. (2013): Cosmogenic surface exposure dating the last deglaciation in Denmark: Discrepancies with independent age contraints suggest delayed periglacial landform stabilisation. - Quaternary Geochronology, 13: 1-17.

Jerz, H. ひ Linke, G. (1987): Arbeitsergebnisse der Subkommission für Europäische Quartärstratigraphie: Typusregion des Holstein-Interglazials (Berichte der SEQS 8). - Eiszeitalter u. Gegenwart, 37: 165-148.

Jouzel, J., Masson-Delmotte, V., Cattani, O., Dreyfus, G., Falourd, G., Hoffmann, G., Minster, B., Nouet, J., Barnola, J.M., Chappellaz, J., Fischer, H., Gallet, J.C., Johnsen, S., Leuenberger, M., Loulergue, L., Luethi, D., Oerter, H., Parrenin, F., Raisbeck, G., Raynaud, D., Schilt, A., Schwander, J., Selmo, E., Souchez, R., Staffer, B., Steffensen, J.P., Stenni, B., Stocker, T.F., Tison, J.L., Werner, M. \& WolfF, E.W. (2007): Orbital and millennial Antarctic climate variability over the past 800,000 years. - Science, Vol. 317: 793-796.

KABEL, C. (1982): Geschiebestratigraphische Untersuchungen im Pleistozän Schleswig-Holsteins und angrenzender Gebiete. - Dissertation Univ. Kiel: 1-132 und 47 S. Anhang.

Kleinmann, A., Müller, H., Lepper, J. \& WaAs, D. (2011): A continental sediment and pollen sequence of the Saalian Complex in NW-Germany and its relationship to the MIS-framework. - Quaternary International, 241(1-2): 97-110

Koutsodendris, A., Müller, C.U., Pross, J., Bauer, A., Kotthoff, U. LotTER, A.F. (2010): Vegetation dynamics and climate variability during the Holsteinian interglacial based on a pollen record from Deth lingen (northern Germany). - Quaternary Science Reviews, 29(23/24) 3298-3307.

Krbetschek, M., Degering, D. \& Alexowsky, W. (2008): Infrarot-Radiofluoreszenz-Alter (IR-RF) unter-saalezeitlicher Sedimente Mittel- und Ostdeutschlands. - Zeitschrift der deutschen Gesellschaft für Geowissenschaften, 159(1): 13-140.

KrbetscheK, M. \& StePhan, H.-J. (2010): Dating of sediments (InfraredRadiofluorescence method IR-RF) at the type locality of the Wacken peat [Kurzfassung und Poster]. - DEUQUA 2010, Tagungsunterlagen/ Conference Proceedings: 117-118; Greifswald (Inst. f. Geografie u. Geologie, Universität Greifswald)

Kronborg, C. (1986): Fine Gravel Content of Tills. In: Møller, J.T. (ed.): Twentyfive years of geology in Aarhus. Geological essays. - Geoskrifter, 24: 189-210; Aarhus (Geologisk Institut, Universitet).

Lippstreu, L., Brose, F. \& MARCineK, J. (1995): Brandenburg. - In: BendA, L. (ed.): Das Quartär Deutschlands: 116-147; Berlin (Gebr. Borntraeger).

LithoLex: Lithostratigraphisches Lexikon, lithostratigraphische Einheiten Deutschlands (Online data bank for lithostratigraphic units of Germany); available from www.bgr.bund.de/litholex

Litt, T., Ellwanger, D., Villinger, E. \& Wansa, S. (2005): Das Quartär in der Stratigraphischen Tabelle von Deutschland 2002. - Newsletter on Stratigraphy, 41: 385-99; Stuttgart.

Litt, T., Behre, K.-E., MeYer, K.-D., Stephan, H.-J. \& WANSA, S. (2007): Stratigraphische Begriffe für das Quartär des norddeutschen Vereisungsgebietes. - E\&G Quaternary Science Journal, 56(1-2): 7-65; Hannover.

Lüthgens, C., Böse, M. \& KRBEtscheK, M. (2009): Towards a new understanding of the Last Glacial Maximum (LGM) in NE-Germany - results from optically stimulated luminescence (OSL) dating and their implications. - Exploratory workshop on the frequency and timing of glaciations in northern Europe (including Britain) during the Middle and Late Pleistocene. Abstracts: 17-18; Berlin (FU).

Lüthgens, C., KrbetscheK, M., Böse, M. \& Fuchs, M.C. (2010): Optically stimulated luminescence dating of fluvioglacial (sandur) sediments from north-eastern Germany. - Quaternary Geochronology, doi:10.1016/j.quageo.2009.06.007.

LütTIG, G. (1957): Geschiebezählungen als Hilfsmittel für die Erforschung des Eiszeitalters und seiner wirtschaftlich wichtigen Lagerstätten. - Die Umschau, 57: 403-405; Frankfurt.

LÜTTIG, G. (1965): Interglacial and interstadial periods. - Journal of Geology, 73: 579-591.

LÜTTIG, G. (1991): Erratic boulder statistics as stratigraphic aid - Examples from Schleswig-Holstein. - Newsletter of Stratigraphy, 25(2): 61-74.

LÜтTIG, G. (1999): Geschiebestatistische Anmerkungen zur Quartärstratigraphie des nordischen Vereisungsgebietes. - Eiszeitalter und Gegenwart, 49: 144-163.

LÜтTIG, G. (2004): Ergebnisse geschiebestatistischer Untersuchungen im Umland von Hamburg. - Archiv für Geschiebekunde, 3(8-12): 729-746; Greifswald.

LÜтTIG, G. (2005): Geschiebezählungen im westlichen Mecklenburg. - Archiv für Geschiebekunde, 4(9): 569-600, 3 Taf.; Greifswald. 
LÜTTIG, G. (2009): Die Bedeutung der Bohrungen von Leck (Quartär, Nordfriesland) für die Geschiebekunde. - Archiv für Geschiebekunde, 5(6) 417-436; Hamburg/Greifswald.

LÜtTIG, G. \& MEYER, K.-D. (2002): Geschiebezählungen in der nördlichen Lüneburger Heide. - Der Geschiebesammler, 34(4): 155-172; Hamburg.

Marks, C., Piotrowski, J.A., Stephan, H.-J., Fedorowicz, S. \& Butrym, J (1995): Thermoluminescence indications of the Middle Weichselian (Vistulian) Glaciation in Northwest Germany. - Meyniana, 47: 69-82; Kiel.

Menke, B. (1968): Beiträge zur Biostratigraphie des Mittelpleistozäns in Norddeutschland. - Meyniana, 18: 35-42.

Menke, B. (1970): Ergebnisse der Pollenanalyse zur Pleistozän-Stratigraphie und zur Pliozän-Pleistozän-Grenze in Schleswig-Holstein. - Eiszeitalter und Gegenwart, 21: 5-21.

Menke, B. (1975): Vegetationsgeschichte und Florenstratigraphie Nordwestdeutschlands im Pliozän und Frühquartär. Mit einem Beitrag zur Biostratigraphie des Weichselfrühglazials - Geologisches Jahrbuch, A26: 3-151, 8 Taf.; Hannover.

Menke, B. (1976): Neue Ergebnisse zur Stratigraphie und Landschaftsentwicklung im Jungpleistozän Westholsteins. - Eiszeitalter und Gegenwart, 27: 53-68.

Menke, B. (1980): Schalkholz. - In: Stremme, H.E. \& Menke, B. (Hrsg.): Quartär-Exkursionen / Quaternary Excursions in Schleswig-Holstein: 70-74; Kiel (Geologisches Landesamt Schleswig-Holstein).

MEYER, K.-D. (1976): Studies on ground moraines in the northwest part of the German Federal Republic. In: Till, its genesis and diagenesis, panel discussion. - UAM, Geografia, 1976: 217-221; Poznán (Uniw. Mickiewicz).

MEYER, K.-D. (1987): Ground and end moraines in Lower Saxony. - In VAN DER MEER, J.J. (ed.): Tills and Glaciotectonics: 197-204; Rotterdam (Balkema).

Meyer, K.-D. (2005): Zur Stratigraphie des Saale-Glazials in Niedersachsen und zu Korrelationsversuchen mit Nachbargebieten. - Eiszeitalter und Gegenwart, 55: 25-42.

Meyer, K.-D. (2012): Stratigraphie des Saale-Komplexes in Niedersachsen und die Schöninger Profile. - In: BeHre, K.-E. (Hrsg.): Die chronologische Einordnung der paläolithischen Fundstellen von Schöningen. Forschungen zur Urgeschichte aus dem Tagebau von Schöningen, Bd. 1: 61-76; Mainz (Römisch-Germanisches Museum).

MüLLER, H. (1986): Altquartäre Sedimente im Deckgebirge des Salzstockes Gorleben. - Zeitschrift der deutschen geologischen Gesellschaft, 137: 85-95.

MüLLER, H. (1992): Climate changes during and at the end of the interglacials of the Cromerian Complex. In: Start of a Glacial, NATO ASI Series I: Global Environmental Change, Vol. 3: 51-70.

MüLlER, U. (2004): Weichsel-Frühglazial in Nordwest-Mecklenburg. - Meyniana, 56: 81-115; Kiel.

MÜLLER, U. (2007): Warnow-Formation. - In: LithoLex [Online-Datenbank] Hannover: BGR. Last updated 05.12.2007 [cited 24.10.2012]. Record No. 1006014. Available from: http//www.bgr.bund.de/litholex

MÜLLER, U. \& OBST, K. (2008): Junge halokinetische Bewegungen im Bereich der Salzkissen Schlieven und Marnitz in Südwest-Mecklenburg. - Brandenburgische Geowissenschaftliche Beiträge, 15(1/): 147-154.

Müller, U., Stephan, H.-J. \& von Bülow, W. (2009): Pommern-Formation. - In: LithoLex [Online-Datenbank]. Hannover: BGR. Last updated 07.05.2009 [cited 01.06.2009]. Record No. 1006001. Available from: http// www.bgr.bund.de/litholex.

Petersen, K.S. \& Kronborg, C. (1991): Late Pleistocene history of the inland glaciation in Denmark. - In: Frenzel, B. (Hrsg.): Klimageschichtliche Probleme der letzten 130000 Jahre; Paläoklimaforschung, Bd. 1: 331-342.

Preusser, F. (1999): Lumineszenzdatierung fluviatiler Sedimente; Fallbeispiele aus der Schweiz und Norddeutschland. - Kölner Forum für Geologie und Paläontologie, 3: 1-62.

Rasmussen, S.O., Andersen, K.K., Svensson, A.A., Steffensen, J.P., Vinther, B.M., Clausen, H.B., Siggard-Andersen, M.-L., Johnsen, S.J., Larsen, L.B., Dahl-Jensen, D., Bigler, M., Röthlisberger, R., Fischer, H., Goto-Azuma, K., Hansson, M.E. \& Ruth, U. (2006): A new Greenland ice core chronology for the last glacial termination. - Journal of Geophysical Research, 111: D06 102, DOI: 10.1029/2005JD006079; $15 \mathrm{pp}$.

RichteR, K. (1937): Die Eiszeit in Norddeutschland. - 1-137; Berlin (Gebr. Borntraeger).

Rinterknecht, V.R., Clark, P.U., Raisbeck, G.M., Yiou, F., Bitinas, A., Brook, E.J., Marks, L., Zelcs, V., LunkKa, J.-P., Pavlovskaya, I.E., Piotrowski, J.A. \& Raukas, A. (2006): The last deglaciation of the southeastern sector of the Scandinavian ice sheet. - Science, vol. 311: $1449-1452$.
Rühberg, N., Schulz, W., v. Bülow, W., Müller, U., Krienke, H.-D., BreMER, F. \& DANN, T. (1995): Mecklenburg-Vorpommern. - In: BENDA, L. (Hrsg.): Das Quartär Deutschlands: 95-115; Berlin (Gebr. Borntraeger).

Sarnthein, M., Stremme, H.E. \& Mangini, A. (1986): The Holstein Interglacial: Time-stratigraphic position and correlation to stable-isotope stratigraphy of deep-sea sediments. - Quaternary Research, 26: 283-293.

Schulz, W. (2003): Geologischer Führer für den norddeutschen Geschiebesammler. - 508 S.; Schwerin (cw-Verlagsgruppe).

Sierralta, M., Frechen, M. \& Urban, B. (2012): Review and new ${ }^{230} \mathrm{U}$ Th dating results from opencast mine Schöningen. - In: BEHRE, K.-E. (Hrsg.): Die chronologische Einordnung der paläolithischen Fundstellen von Schöningen. Forschungen zur Urgeschichte aus dem Tagebau von Schöningen, Bd. 1: 143-154; Mainz (Römisch-Germanisches Zentralmuseum).

STEPHAN, H.-J. (1980): Glazialgeologische Untersuchungen im südlichen Geestgebiet Dithmarschens. - Schriften des Naturwissenschaftlichen Vereins für Schleswig-Holstein, 50: 1-36; Kiel.

Stephan, H.-J. (1982): The subdivision of the glacial Pleistocene in Schleswig-Holstein and problems of correlations with adjacent areas. - XI. INQUA-Congress 1982, Moskva, Abstracts, Vol. II: 313; Moscow.

StEPHAN, H.-J. (1987): Moraine stratigraphy in Schleswig-Holstein and adjacent areas. - In: VAN Der MEER, J.J.M. (ed.): Tills and Glaciotectonics: 23-30; Rotterdam (Balkema)

Stephan, H.-J. (1995): Schleswig-Holstein. - In: BendA, L. (Hrsg.): Das Quartär Deutschlands: 1-13; Berlin/Stuttgart (Gebr. Borntraeger).

STEPHAN, H.-J. (1998): Geschiebemergel als stratigraphische Leithorizonte in Schleswig-Holstein; ein Überblick: - Meyniana, 50: 113-135; Kiel.

Stephan, H.-J. (2001): The Young Baltic advance in the western Baltic depression. - Geological Quarterly, 45(4): 359-363; Warszawa.

StePHAN, H.-J. (2003): Zur Entstehung der eiszeitlichen Landschaft Schleswig-Holsteins. - Schriften des Naturwissenschaftlichen Vereins für Schleswig-Holstein, 67: 101-118; Kiel.

STEPHAN, H.-J. (2004): Karte der Stauchgebiete und Haupt-Gletscherrandlagen in Schleswig-Holstein 1: 500.000. - Meyniana, 56: 149-154, 1 Karte; Kiel.

StEPHAN, H.-J. (2005): Zur weichselzeitlichen Landschaftsentwicklung der wagrischen Halbinsel. - 72. Tagung der Norddeutschen Geologen in der Hansestadt Lübeck 2005, Tagungsband und Exkursionsführer (Exkursion B1): 129-140; Flintbek (LANU Schleswig-Holstein).

STEPHAN, H.-J. (2006a): Ellund-Formation. - In: LithoLex [Online-Datenbank]. Hannover: BGR. Last updated 14.05.2007 [cited 06.12.2008]. Record No. 1006002. Available from: http//www.bgr.bund.de/litholex.

STEPHAN, H.-J. (2006b): Leck-Formation. - In: LithoLex [Online-Datenbank] Hannover: BGR. Last updated 14.05.2007 [cited 06.12.2008]. Record No. 1006003. Available from: BGR. http//www.bgr.bund.de/litholex.

StEPHAN, H.-J. (2007): Goldelund-Formation. - In: LithoLex [Online-Datenbank]. Hannover: BGR. Last updated 15.11.2007 [cited 06.12.2008]. Record No. 1006022. Available from: http//www.bgr.bund.de/litholex .

STEPHAN, H.-J. (2011): Geschiebestratigraphische Untersuchungen im Bereich der Stauchmoräne Kisdorfer Wohld, Südholstein und in ihrem Hinterland. - Geschiebekunde aktuell. Sonderh. 9: 113-124

Stephan, H.-J. ש Menke, B. (1993): Das Pleistozän in Schleswig-Holstein. GLA SH, 3: 19-62, 1 Fototaf. (Abb. 3-4); Kiel (Geologisches Landesamt Schleswig-Holstein).

STEPHAN, H.-J. \& MÜlLER, U. (2007): Brandenburg-Formation. - In: LithoLex [Online-Datenbank]. Hannover: BGR. Last updated 06.09.2011 [cited 24.10.2012]. Record No. 1006010. Available from: http//www.bgr. bund.de/litholex.

StePhan, H.-J., Müller, U. \& von Bülow, W. (2008): Frankfurt(Oder)-Formation. - In: LithoLex [Online-Datenbank]. Hannover: BGR. Last updated 05.12.2008 [cited 01.06.2009]. Record No. 1006011. Available from: http//www.bgr.bund.de/litholex.

Stephan, H.-J., Urban, B., Lüttig, G., Menke, B. \& Sierralta, M. (2011) Palynologische, petrographische und geochronologische Untersuchungen an Ablagerungen der Leck-Warmzeit (spätes Mittelpleistozän) und begleitender Sedimente. - Geologisches Jahrbuch, 160: 3-80

Stremme, H.E. \& Menke, B. (Hrsg.) (1980): Quartär-Exkursionen, Quaternary-Excursions in Schleswig-Holstein. - 132 S., 4 Ktn.; Kiel (Geologisches Landesamt Schleswig-Holstein).

Stuiver, M., Grootes, P.M. \& Braziunas, T.F. (1995): The GISP2 $\delta^{18} \mathrm{O}$ climate record of the past 16500 years and the role of the sun, ocean, and volcanoes. - Quaternary research, 44: 341-354.

Stuiver, M. \& Grootes, P.M. (2000): Isotope Ratios. - Quaternary Research, 53: 277-284.

Turner, C. (1996): A brief survey of the early Middle Pleistocene of Europe. - In: Turner, C. (ed.): The early Middle Pleistocene in Europe: 295-317; Rotterdam (A.A. Balkema). 
URBAN, B. (1978): Vegetationsgeschichtliche Untersuchungen zur Gliederung des Altquartärs der Niederrheinischen Bucht. - Sonderveröffentlichungen des geologischen Instituts der Universität Köln, 34: 1-165; Köln.

Urban, B. (1995): Younger Middle Pleistocence Interglacials (Holsteinian, Reinsdorf, Schöningen) in the Schöningen open cast lignite mine (Eastern Lower Saxony/Germany). - Mededelingen Rijks Geologische Dienst, 52: 175-186.

URBAN, B. (2007): Quartäre Vegetations- und Klimaentwicklung im Tagebau Schöningen. - In: Thieme, H.: Die Schöninger Speere - Mensch und Jagd vor 400000 Jahren: 65-75; Stuttgart (Theiss Verlag).

Urban, B., Sierralta, M. \& Frechen, M. (2011): New evidence for vegetation development and timing of Upper Middle Pleistocene interglacials in Northern Germany and tentative correlations. - Quaternary International, 241: 125-142.

Urban, B. \& Sierralta, M. (2012): New palynological evidence and correlation of Palaeolithic sites Schöningen 12 B and 13 II, Schöningen open lignite mine. - In: BEHRE, K.-E. (Hrsg.): Die chronologische Einordnung der paläolithischen Fundstellen von Schöningen. Forschungen zur Urgeschichte aus dem Tagebau von Schöningen, Bd. 1: 77-96; Mainz (Römisch-Germanisches Zentralmuseum).

Usinger, H. (1985): Pollenstratigraphische, vegetations- und klimageschichtliche Gliederung des Bölling-Alleröd-Komplexes in Schleswig-Holstein und ihre Bedeutung für die Spätglazial-Stratigraphie in benachbarten Gebieten. - Flora, 177: 1-430; Leipzig.

Vinxs, R., Grube, A.T. \& Grube, F. (1997): Lithologie, Geschiebeführung und Geochemie eines Prä-Elster I-Tills von Lieth bei Elmshorn. - Leipziger Geowissenschaften, 5: 83-103; Leipzig.

Walker, M., Johnsen, S., Rasmussen, S.O., Popp, T., Steffensen, J.-P., Gibbard, P., Hoek, W., Lowe, J., Andrews, J., BJörck, S., Cwynar, L.C., Hughen, K., Kershaw, P., Kromer, B., Litt, T., Lowe, D.J., Nakagawa, T., Newnham, R. \& Schwander, J. (2009): Formal definition and dating of the GSSP (Global Stratotype Section and Point) for the base of the Holocene using the Greenland NGRIP ice core, and selected auxiliary records. - Journal of Quaternary Science, vol. 24(1): 3-17.

WenNBerg, G. (1949): Differentialrörelser i Inlandsisen sista Istiden i Danmark, Skåne och Östersjön. - Meddelanden Lunds Geologisk-Mineralogiske Institut, 114: 1-201, 1 pl, 46 p. tab.; Lund (Carl Blohm).

Woldstedt, P. (1926): Die großen Endmoränenzüge Norddeutschlands. - Zeitschrift der Deutschen Geologischen Gesellschaft, 77 (für 1925): $172-184,1 \mathrm{Kt}$. .

WoldstedT, P. (1928): Die Parallelisierung des nordeuropäischen Diluviums mit dem anderer Vereisungsgebiete. - Zeitschrift für Gletscherkunde, 16(3/4): 230-241; Berlin.

Woldstedt, P. (1954): Saaleeiszeit, Warthestadium und Weichseleiszeit in Norddeutschland. - Eiszeitalter und Gegenwart, 4/5: 34-48.

Woldstedt, P. \& Duphorn, K. (1974): Norddeutschland und angrenzende Gebiete im Eiszeitalter. - 500 S.; Stuttgart (K.F. Köhler).

Wolff, E.W., Chappellaz, J., Blunier, T. Rasmussen, S.O. \& Svensson, A (2010): Millennial-scale variability during the last glacial: The ice core record. - Quaternary Science Reviews, 29(21-22): 2828-2838.

ZAGwIN, W.H. (1960): Aspects of the Pliocene and early Pleistocene vegetation in the Netherlands. - Mededelingen van de Geologische Stichting, Ser. C-III-1(5): 1-78.

Zagwin, W.H. (1963): Pollenanalytical investigations in the Tiglian of the Netherlands. - Mededelingen van de Geologische Stichting. N.S., 16: 49-71.

ZaGwin, W.H. (1996): The Cromerian Complex Stage of the Netherlands and correlation with other areas in Europe. - In: Turner, C. (ed.): The Middle Pleistocene in Europe: 145-172; Rotterdam (Balkema).

Zagwin, W.H. \& DE Jong (1984): Die Interglaziale von Bavel und Leerdam und ihre stratigraphische Stellung im niederländischen Früh-Pleistozän. - Mededelingen Rijks Geologische Dienst, 37: 155-169.

Zagwijn, W.H., van Montfrans, H.M., Zandstra, J.G. (1971): Subdivision of the "Cromerian" in the Netherlands, pollenanalysis, paleomagnetism and sedimentary petrology. - Geologie en Mijnbouw, 50: 41-58.
Klimastratigraphische Gliederung des Pleistozäns in Schleswig-Holstein

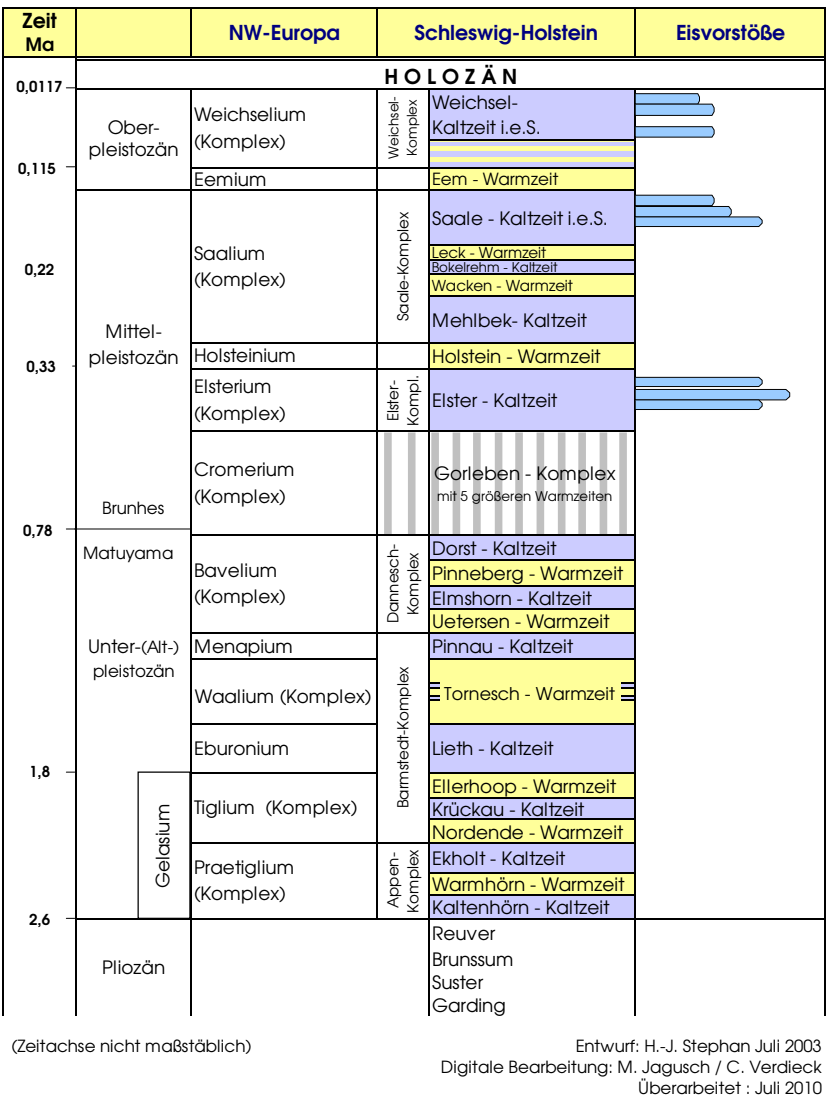

Appendix Fig. 11: Original German version of the climato-stratigraphical table of Fig. 3.

Anhang Abb. 11: Die originale deutsche Version der klimastratigraphischen Tafel von $A b b .3$ 